\title{
Dietary restriction of mice on a high-fat diet induces substrate efficiency and improves metabolic health
}

\author{
Loes P M Duivenvoorde, Evert M van Schothorst, Annelies Bunschoten and Jaap Keijer \\ Department of Human and Animal Physiology, Wageningen University, Marijkeweg 40, 6709 GP Wageningen, PO Box 338, 6700 AH Wageningen, The Netherlands \\ (Correspondence should be addressed to E M van Schothorst; Email: evert.vanschothorst@wur.nl)
}

\begin{abstract}
High energy intake and, specifically, high dietary fat intake challenge the mammalian metabolism and correlate with many metabolic disorders such as obesity and diabetes. However, dietary restriction (DR) is known to prevent the development of metabolic disorders. The current western diets are highly enriched in fat, and it is as yet unclear whether DR on a certain high-fat (HF) diet elicits similar beneficial effects on health. In this research, we report that HF-DR improves metabolic health of mice compared with mice receiving the same diet on an ad libitum basis (HF-AL). Already after five weeks of restriction, the serum levels of cholesterol and leptin were significantly decreased in HF-DR mice, whereas their glucose sensitivity and serum adiponectin levels were increased. The body weight and measured serum parameters remained stable in the following 7 weeks of restriction, implying metabolic adaptation. To understand the molecular events associated with this adaptation, we analyzed gene expression in white adipose tissue (WAT) with whole genome microarrays. HF-DR strongly influenced gene expression in WAT; in total, 8643 genes were differentially expressed between both groups of mice, with a major role for genes involved in lipid metabolism and mitochondrial functioning. This was confirmed by quantitative real-time reverse transcription-PCR and substantiated by increase in mitochondrial density in WAT of HF-DR mice. These results provide new insights in the metabolic flexibility of dietary restricted animals and suggest the development of substrate efficiency.
\end{abstract}

Journal of Molecular Endocrinology (2011) 47, 81-97

\section{Introduction}

Obesity is a major health concern that affects millions of people worldwide (Kopelman 2000, Ogden et al. 2010). Although white adipose tissue (WAT) plays an important role in mammalian energy homeostasis by preventing lipotoxicity and providing a source of energy in times of need, excess amounts of WAT relates to reduction in the number of mitochondria and inflammation of the tissue (Semple et al. 2004, Dahlman et al. 2006), subsequently resulting in metabolic dysfunction (Trayhurn \& Beattie 2001, Keijer \& van Schothorst 2008). Obesity is associated with several serious complications including type 2 diabetes, coronary heart disease, and certain types of cancer and, therefore, significantly increases morbidity risks in those affected (Sobel et al. 2003). The current prevalence of obesity most likely resulted from the notable decrease in overall physical activity and increase in consumption of readily available energy-dense foods (Ledikwe et al. 2006). Fast foods, for example, as supplied by some typical outlets, contain an average energy density that is more than twice the energy density of a recommended healthy diet, and the energy density of food highly correlates with the fat content of a meal (Prentice \& Jebb 2003). Consistently, the WHO concluded that, in the period from 2000 to 2003, the average European diet consisted of $35-40 \%$ of energy available from fat; in France and Spain, this proportion was even higher (WHO/Europe, European HFA Database, July 2010).

Restriction on dietary intake (dietary restriction, DR) is known to robustly improve metabolic health (Lee et al. 1999, Rezzi et al. 2009). Long-term DR extends maximum lifespan and opposes the development of a broad array of age-associated biological and pathological changes in a diverse range of organisms (Weindruch et al. 1988). DR studies in mice and other species have led to detailed descriptions of changes in gene expression in different tissues (Lee et al. 1999, 2002, Higami et al. 2004, van Schothorst et al. 2006, Linford et al. 2007) and various mechanisms that are implicated in the beneficial health effects. Among the DR-related biomarkers, there is increase in mitochondrial density in adipocytes (Lambert et al. 2004) and increase in insulin sensitivity (Lara-Castro et al. 2008). Most studies examining the effects of DR, however, have been performed in standard rodent diets that are characterized by a low-fat content $(7-9 \%$ energy from fat). Only few studies focused on the effect of DR using high-fat diets (HF-DR; Petro et al. 2004, Kalupahana et al. 2011, de Meijer et al. 2010), which is, in fact, more relevant to the current dietary status in most developed countries.

DOI: 10.1530/JME-11-0001 Online version via http://www.endocrinology-journals.org 
In this study, we therefore examined the effects of DR in the context of a semi-synthetic AIN93-based diet that contains 30\% energy from fat and compare metabolic adaptation and metabolic health of mice that received the diet either on a restricted (30\%) or ad libitum (HF-AL) basis. We show that, although an animal is fed a HF (western) diet, the moderate reduction in the total amount of calories improves metabolic health, as measured by a number of parameters, such as glucose tolerance and serum cholesterol, leptin, and adiponectin levels. Whole genome gene expression analysis of WAT revealed a strong upregulation of genes involved in mitochondrial function and lipid metabolism by HF-DR. Relative to results obtained with standard diets, in particular, lipid handling is affected, implying the development of substrate efficiency in HF-DR mice. Finally, we observed increase in mitochondrial density in WAT of HF-DR mice.

\section{Materials and methods}

\section{Animals and dietary manipulations}

We used 36 male C57BL/6JOlaHsd mice (Harlan Laboratories, Horst, The Netherlands) aged 10 weeks for this study. The experimental protocol was approved by the Animal Welfare Committee of Wageningen University, Wageningen, The Netherlands. Mice were individually housed and maintained under environmentally controlled conditions (temperature $21^{\circ} \mathrm{C}, 12 \mathrm{~h}$ light: $12 \mathrm{~h}$ darkness cycle, $45 \%$ humidity) and had, during the first 3 weeks (the adaptation phase), access to food and water ad libitum. The food consisted of a palletized diet (Research Diets Services B.V., Wijk bij Duurstede, The Netherlands) with a fat content of $30 \%$, which resembles a western human diet (Table 1). The amount of lard and corn oil are also based on average human intake levels. The diet that was used for DR was in ratio supplemented with a vitamin and mineral premix to guarantee the same level of intake as in the non-restricted group to prevent deficiencies. As the mineral and vitamin premixes contain cornstarch, the HF-DR diet is corrected in the carbohydrate fraction.

At $t=0$ weeks, animals were stratified on body weight and divided into groups of 12 animals. The first treatment group $(t=0)$ was directly culled after the adaptation phase, the HF-AL group remained under the same conditions, whereas the HF-DR group received a DR of 30\%, which lasted for 12 weeks. The amount of restricted food depended on the amount individual mice consumed at the end of the adaptation phase and remained unchanged during the whole intervention phase. The bodyweight and food intake of individual mice were monitored on a weekly basis. The HF-DR group received a fixed amount of feed on a daily basis. All mice were culled at the end of the 12-week intervention.
Table 1 Diet composition of the HF-AL and HF-DR diets in $\mathrm{g} / \mathrm{kg}$ of the diet and based on relative intake. The HF-AL diet was fed ad libitum; the HF-DR animals received $70 \%$ energy of the HF-DR diet compared with the HF-AL animals. Both diets were iso-caloric in the lipid, protein, and carbohydrate fraction. The HF-DR diet was adjusted for the amount of vitamins and minerals to ensure a homologous intake between both groups

\begin{tabular}{|c|c|c|c|c|}
\hline Component & $\begin{array}{l}\text { HF-AL } \\
\text { (g/kg } \\
\text { feed) }\end{array}$ & $\begin{array}{l}\text { HF-DR } \\
\text { (g/kg } \\
\text { feed) }\end{array}$ & $\begin{array}{l}\text { AL } \\
\text { intake } \\
\text { HF-AL } \\
\times 1\end{array}$ & $\begin{array}{l}\text { DR } \\
\text { intake } \\
\text { HF-DR } \\
\times 0.7\end{array}$ \\
\hline Acid casein & 220 & 220 & 220 & 154 \\
\hline L-cystine & 3 & 3 & 3 & $2 \cdot 1$ \\
\hline Starch & $336 \cdot 7$ & $331 \cdot 3$ & $336 \cdot 7$ & $231 \cdot 9$ \\
\hline Maltodextrose & $112 \cdot 25$ & $110 \cdot 4$ & $112 \cdot 25$ & $77 \cdot 3$ \\
\hline Sucrose & 85.5 & $84 \cdot 1$ & 85.5 & 58.9 \\
\hline Cellulose (Arbocel B800) & 50 & $38 \cdot 3$ & 50 & $26 \cdot 8$ \\
\hline Lard & $101 \cdot 5$ & $101 \cdot 5$ & $101 \cdot 5$ & $71 \cdot 1$ \\
\hline Corn oil & 43.5 & $43 \cdot 5$ & $43 \cdot 5$ & $30 \cdot 5$ \\
\hline Mineral premix AIN-93G & 35 & 50 & 35 & 35 \\
\hline Vitamin premix AIN-93 & 10 & $14 \cdot 3$ & 10 & 10 \\
\hline Choline bitartrate & $2 \cdot 5$ & 3.5 & $2 \cdot 5$ & $2 \cdot 5$ \\
\hline Energy (kcal/kg) & 4375 & 4375 & & \\
\hline Energy $\%$ from fat & 30 & 30 & & \\
\hline Energy \% from proteins & 20 & 20 & & \\
\hline Energy \% from carbohydrates & 50 & 50 & & \\
\hline
\end{tabular}

\section{WAT and blood collection (at time of section)}

The HF-AL and $t=0$ mice were fasted for $2 \mathrm{~h}$ before sectioning. To match the level of food intake before sectioning to the HF-AL group, HF-DR mice received the regular (restricted) amount of food on the habitual time in the morning and were sectioned $6 \mathrm{~h}$ afterward. At the time point of section, mice were anesthetized by inhalation of $5 \%$ isoflurane. Blood was sampled after eye extraction and collected in Mini collect serum tubes (Greiner Bio-one, Longwood, FL, USA) and centrifuged for $10 \mathrm{~min}$ at $3000 \mathrm{~g}$ and $4{ }^{\circ} \mathrm{C}$ to obtain serum. Serum samples were aliquoted and stored at $-80^{\circ} \mathrm{C}$. After blood collection, mice were killed using cervical dislocation and epididymal WAT was dissected, weighted, and snap frozen in liquid nitrogen and stored at $-80{ }^{\circ} \mathrm{C}$.

\section{RNA isolation, cDNA synthesis, and microarray hybridization}

RNA isolation from WAT was performed as described (Van Schothorst et al. 2005). Briefly, WAT was homogenized in liquid nitrogen using a cooled mortar and pestle. Total RNA was isolated using TRIzol reagent, chloroform, and isoamyl alcohol (PCI; Invitrogen) followed by purification with RNeasy columns (Qiagen) using the instructions of the manufacturer. RNA concentration and purity were measured using the Nanodrop (IsoGen Life Science, Maarssen, The Netherlands). Approximately, $30 \mu \mathrm{g}$ total RNA was isolated with 
A260/A280 ratios above 2 and A260/A230 ratios above 1.9 for all samples, indicating good RNA purity. RNA quality was additionally checked on the Experion automated electrophoresis system (Bio-Rad) using Experion StdSense chips (Bio-Rad).

For transcriptome analysis, the $4 \times 44 \mathrm{k}$ Agilent whole-mouse genome microarrays (G4122F, Agilent Technologies, Inc., Santa Clara, CA, USA) were used. Preparation of the samples and the microarray hybridizations were carried out according to the manufacturer's protocol with a few modifications as described previously (van Schothorst et al. 2007, van Helden et al. 2010). All materials and reagents are from Agilent Technologies, Palo Alto, CA, USA, unless stated. In brief, cDNA was synthesized for each animal from $1 \mu \mathrm{g}$ WAT RNA using the Agilent Low-RNA Input Fluorescent Linear Amplification Kit without addition of spikes. Thereafter, samples were split into two equal amounts to synthesize cyanine 3-CTP (Cy3) and cyanine 5-CTP (Cy5) labeled cRNA, using half the amounts per dye as indicated by the manufacturer. Labeled cRNA was purified using RNeasy columns (Qiagen). Yield and Cy-dye incorporation were examined for every sample using the Nanodrop. All samples met the criteria of a cRNA yield higher than $825 \mathrm{ng}$ and a specific activity of at least 8.0 pmol Cy-dye per $\mu \mathrm{g}$ cRNA. Then, Cy3labeled cRNA samples were pooled on an equimolar basis and used as a common reference pool. Individual 825-ng Cy5-labeled cRNA and 825-ng pooled Cy3labeled cRNA were fragmented in $1 \times$ fragmentation and $1 \times$ blocking agent at $60^{\circ} \mathrm{C}$ for $30 \mathrm{~min}$ and thereafter mixed with GEx hybridization buffer HI-RPM. Individual Cy5-labeled cRNA and pooled Cy3-labeled cRNA were hybridized to the arrays in a $1: 1$ ratio at $65^{\circ} \mathrm{C}$ for $17 \mathrm{~h}$ in the Agilent Microarray Hybridization Chamber rotating at 10 r.p.m. Samples were randomly divided over the slides and positions on the slides. After hybridization, slides were washed according to the manufacturer's wash protocol. Arrays were scanned with an Agilent Technologies Scanner G2505B with 10 and $100 \%$ laser power intensities.

\section{Normalization and statistical analysis of microarray data}

Signal intensities for each spot were quantified using Feature Extraction version 9.5.3.1 (Agilent Technologies). Median density values and background values of each spot were extracted for both the individual samples (Cy5) and the pooled samples (Cy3). Quality control for every microarray was performed visually by using 'quality control graphs' from Feature extraction and M-A plots and box plots, which were made using limmaGUI in $\mathrm{R}$ (Wettenhall \& Smyth 2004). Data were imported into GeneMaths XT 2.0 (Applied Maths, Sint-Martens-Latem, Belgium).
Spots with an average Cy5 and Cy3 signal twice above background were selected and $\log$ transformed. The Cy5 signal was normalized against the Cy3 intensity as described before (Pellis et al. 2003). All arrays are deposited in GEO under the number GSE27213. Supervised principal component analysis and heat mapping were performed using GeneMaths XT. Volcano plots were made using GraphPad Prism version 5.03 (Graphpad Software, San Diego, CA, USA). Gene expression levels of the HF-DR versus the HF-AL groups were analyzed by Student's $t$-tests using a multiple testing correction according to Benjamini-Hochberg (Hochberg \& Benjamini 1990). Corrected $P$ values $<0.01$ were considered as statistically significant. Fold change is expressed as the ratio of the HF-DR group over the HF-AL group. For downregulated genes, the fold change is converted to the corresponding negative value. Pathway analysis was performed using MetaCore (GeneGo, St Joseph, MI, USA), GO overrepresentation analysis, and literature mining.

\section{Quantitative real-time reverse transcription-PCR}

Quantitative real-time reverse transcription-PCR (qRTPCR) was performed on individual samples as described previously (de Boer et al. 2006, van Schothorst et al. 2009b) to validate the microarray data. RNA $(1 \mu \mathrm{g})$ of all individual samples was used for cDNA synthesis using the iScript cDNA synthesis kit (Bio-Rad). qRT-PCRs were performed with iQ SYBR Green Supermix (Bio-Rad) using the MyIQ single-color real-time PCR detection system (Bio-Rad). Each reaction $(25 \mu \mathrm{l})$ contained 12.5 $\mu \mathrm{l}$ iQ SYBR Green Supermix, $1 \mu \mathrm{l}$ forward primer $(10 \mu \mathrm{M})$, $1 \mu \mathrm{l}$ reverse primer $(10 \mu \mathrm{M}), 8.5 \mu \mathrm{l}$ RNase-free water, and $2 \mu \mathrm{l} 100 \times$ diluted cDNA. The following cycles were performed: one initialization step of $3 \mathrm{~min}$ at $95^{\circ} \mathrm{C}, 40$ amplification cycles $\left(15 \mathrm{~s}\right.$ at $95^{\circ} \mathrm{C}$ and $45 \mathrm{~s}$ at the optimal annealing temperature), and one final cycle of $1 \mathrm{~min}$ at $95^{\circ} \mathrm{C}$ and $1 \mathrm{~min}$ at $65^{\circ} \mathrm{C}$. Finally, a melting curve was prepared $\left(60\right.$ cycles of $10 \mathrm{~s}$ at $65^{\circ} \mathrm{C}$ with an increase of $0.5^{\circ} \mathrm{C}$ per $10 \mathrm{~s}$ ). A standard curve using serial dilutions of pooled sample (cDNA from all samples), a negative control without cDNA template, and a negative control without reverse transcriptase $(-\mathrm{RT})$ were taken along with every assay. Only standard curves with efficiency between 90 and $110 \%$ and a correlation coefficient $>0.99$ were accepted. Individual samples were measured in duplicate. Data were normalized against the geometrical mean of the reference genes calnexin (Canx), $\beta-2$ microglobulin $(B 2 m)$, ribosomal protein S15 (Rps15), and endoplasmic reticulum chaperone SIL1 homolog (Sil1), which were chosen based on stable gene expression levels between the mice on the microarray and confirmed with the resulting qRT-PCR data (geNorm, Ghent University Hospital, Ghent, Belgium). Primers were designed using the NCBI Primer-Blast 
Table 2 Primer sequences and PCR annealing temperatures of the primers used for quantitative real-time reverse transcription-PCR (qRT-PCR). Genes denoted with an asterisk were used as reference genes

\begin{tabular}{|c|c|c|c|}
\hline Genes & Forward primer $5^{\prime}-3^{\prime}$ & Reverse primer $5^{\prime}-3^{\prime}$ & temperatures $\left({ }^{\circ} \mathrm{C}\right)$ \\
\hline Acaca & AGCAGATCCGCAGCTTGGTC & CGGGAAGCTCСTCСTACGTG & $60 \cdot 0$ \\
\hline Acly & TGGGCTTCATTGGGCACTACC & AGGGCTCCTGGCTCAGTTACA & $62 \cdot 0$ \\
\hline Elovl3 & TGTTGAACTGGGAGACACGGC & GTCATGAACCAGCCACCCGA & $62 \cdot 0$ \\
\hline Elovl6 & GGCACTAAGACCGCAAGGCA & GCTACGTGTTCTCTGCGCCT & $60 \cdot 0$ \\
\hline Fasn & AGTTAGAGCAGGACAAGCCCAAG & GTGCAGAGCTGTGCTCCTGA & $60 \cdot 0$ \\
\hline Sqle & CCGGAAAGCAGCTATGGCAGA & GCGTGGAGCTCCTTGGTGTC & $62 \cdot 0$ \\
\hline Srebf1 & TCCAGTGGCAAAGGAGGCAC & CAGCATGCTCATTCGCTGCC & $60 \cdot 0$ \\
\hline$B 2 m^{*}$ & CCCCACTGAGACTGATACATACGC & AGAAACTGGATTTGTAATTAAGCAGGTTC & $60 \cdot 0$ \\
\hline Canx $x^{\star}$ & GCAGCGACCTATGATTGACAACC & GCTCCAAACCAATAGCACTGAAAGG & $62 \cdot 0$ \\
\hline $\operatorname{Rps15^{\star }}$ & CGGAGATGGTGGGTAGCATGG & ACGGGTTTGTAGGTGATGGAGAAC & $62 \cdot 0$ \\
\hline Sil1* & GGCCGCCTTTTCCAGCAATC & CGGGGAGAGGCTGGTTTGTG & $62 \cdot 0$ \\
\hline
\end{tabular}

(NCBI Web site) and Beacon designer (Premier Biosoft International, Palo Alto, CA, USA). The primer sequences and PCR annealing temperatures for each gene are summarized in Table 2.

\section{Oral glucose tolerance test}

Oral glucose tolerance was tested in all mice of the HF-AL and HF-DR group at $t=5,8$, and 11 weeks of the dietary intervention. At $t=0$ weeks, before the switch to the different dietary interventions, glucose tolerance was tested in three mice per group. On the days that the oral glucose tolerance tests (OGTTs) took place, HF-DR mice received their daily amount of food after the OGTT. Food of all mice was removed at the start of the light phase and $5 \mathrm{~h}$ afterward tail blood $(\sim 50 \mu \mathrm{l})$ was collected and partly used to determine the glucose concentration with an automated blood glucose monitoring system (Freestyle, Abbott Diabetes Care). Remaining blood was transferred to Mini collect serum tubes (Greiner Bio-one) and centrifuged for $10 \mathrm{~min}$ at $3000 \mathrm{~g}$ and $4{ }^{\circ} \mathrm{C}$ to obtain serum; serum samples were stored at $-80^{\circ} \mathrm{C}$. Glucose $(2 \mathrm{~g} / \mathrm{kg} \mathrm{BW})$ was given orally by gavage at the start of each experiment. Tail blood $(3 \mu \mathrm{l})$ was collected $15,30,60,90$, and $120 \mathrm{~min}$ after glucose administration and used to determine the glucose concentration with the automated blood glucose monitoring system. The incremental area under the curve of the changes in blood glucose over time per mouse was calculated using GraphPad Prism.

\section{Serum measurements}

Serum samples of the starting point $(t=0 \mathrm{~min})$ of each of the OGTTs were used to measure serum leptin, insulin, and adiponectin in fasted animals with the mouse serum adipokine Lincoplex Kit (Linco Research, Nuclilab, Ede, The Netherlands). Preparation of the samples and binding to the antibody-coupled beads were carried out according to the manufacturer's protocol with a few modifications as described previously (van Schothorst $e t a l$. 2009a). In short, sera were diluted 5 times in HPE buffer (Sanquin, Amsterdam, The Netherlands), debris was removed by spinning the sample using SpinX columns (Corning, Schiphol-Rijk, The Netherlands), and possible inhibition of the immunological Ig fraction in serum was circumvented by an incubation at gentle shaking for $1 \mathrm{~h}$ at room temperature in 96-well Reacti-BindTM protein L-coated plates (Pierce, Rockford, IL, USA) before adipokine assaying. The assays were measured using the Luminex X100 system (Bio-Rad) with Starstation software (Applied Cytometry Systems, Dinnington, Sheffield, UK). Sample concentrations were calculated using a standard curve of the metabolite of interest (supplied by the kit). All individual samples were analyzed in duplicate and averaged.

Serum total cholesterol, high-density lipoprotein (HDL)-cholesterol, and triglycerides were measured using liquicolor enzymatic colorimetric tests (Human, Wiesbaden, Germany). Measured serum triglyceride concentrations were corrected for free serum glycerol concentrations, using a glycerol colorimetric method (Instruchemie, Delfzijl, The Netherlands). Serum samples $(2 \mu \mathrm{l})$ were measured in duplicate and averaged. Sample concentrations were calculated using a standard curve of the metabolite of interest (supplied by the kit). Serum low-density lipoprotein (LDL)-cholesterol concentrations were calculated using the modified (for rodents) Friedewald formula (LDL-cholesterol $=$ total cholesterol - HDL - cholesterol(triglycerides $\times 0 \cdot 16)$ ) (Friedewald et al. 1972).

\section{Mitochondrial mass measurement}

To estimate the mitochondrial density in WAT of HF-AL, HF-DR, and $t=0$ mice, we determined the 
ratio of mitochondrial DNA to nuclear DNA with qRTPCR according to Lagouge et al. (2006). Total DNA was isolated from $25 \mathrm{mg}$ WAT using the QIAamp DNA minikit (Qiagen). Quality and quantity of DNA in each sample was analyzed with the Nanodrop and each sample was diluted to the same concentration. qRT-PCR was performed with mitochondrial DNA and genomic DNA-specific primers (Lagouge et al. 2006). A standard curve for both genes was generated using serial dilutions of a pooled sample (DNA from all samples). Only standard curves with an efficiency between 90 and $110 \%$ and a correlation coefficient $>0.99$ were accepted. Samples were measured in duplicate. The individual relative mitochondrial density was calculated as the $C_{\mathrm{t}}$ value of the mitochondrial gene compared with the $C_{\mathrm{t}}$ value of the nucleic gene in the same sample.

\section{Statistical analysis of serum samples, WAT weight, and OGTT}

Data are expressed as mean \pm s.E.M.; statistical analyses were performed using GraphPad Prism. All individual measurements within the different treatment groups were checked for normality using the D'AgostinoPearson normality test. Test results that were not normally distributed were $\log$ transformed. Measurements at single time points between two groups were analyzed by Student's $t$-tests. Measurements at single time points among three groups were analyzed by oneway ANOVA and Bonferroni post hoc analysis. $P<0 \cdot 05$ was considered as statistically significant.

\section{Results}

\section{HF-DR decreased body weight and WAT weight}

Body weight of HF-DR animals declines after the start of the intervention and stabilizes after $\sim 5$ weeks, whereas HF-AL-fed mice gained weight throughout the study (Fig. 1A). At the time point of section, 12 weeks after the adaptation phase, HF-DR mice showed a significant decrease in absolute and relative epididymal WAT weight compared with HF-AL mice (Fig. 1B and C).

\section{HF-DR mice performed better on the OGTT and had decreased fasting glucose and insulin levels}

In a fasted state, HF-AL and HF-DR mice significantly differed in serum levels of markers that predict the onset of insulin resistance; at 5, 8, and 11 weeks after the start of the intervention, OGTTs indicated that the insulin sensitivity of the HF-DR mice was considerably higher than that of HF-AL mice (Fig. 2A and B). Secondly, the HF-DR group had significantly lower serum levels of glucose and insulin (Fig. 2C and D).
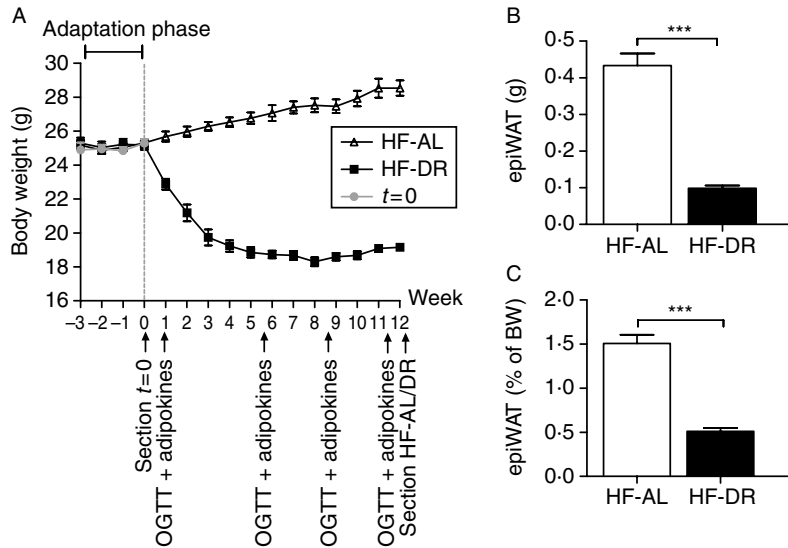

Figure 1 Changes in body and white adipose tissue (WAT) weight of mice on either a dietary restricted high-fat diet (HF-DR) or highfat diet fed ad libitum (HF-AL). (A) During the adaptation phase, HF-AL, HF-DR, and $t=0$ mice had similar body weights. During the first 5 weeks of the restriction period, HF-DR mice gradually lost body weight, after which body weight stabilized. (B and $C$ ) HF-DR mice exhibit a significant decrease in absolute and relative epididymal WAT weight at the time of section. Data are mean \pm S.E.M. of 12 mice. ${ }^{* \star} P<0 \cdot 0001$.

It should be noted that insulin levels of most of the HF-DR animals ( $\sim 9$ per measurement) were below the detection limit of the serum adipokine kit; these values were set to half the value of the detection limit $(0 \cdot 13 \mathrm{nM})$.

\section{Serum leptin, adiponectin, and cholesterol levels were significantly altered in HF-DR mice}

Leptin concentrations were significantly lowered in HF-DR animals (Fig. 3A), whereas serum adiponectin levels were significantly elevated after 5,8 , and 11 weeks of DR (Fig. 3C). At the end of the dietary intervention, total cholesterol was significantly lowered in HF-DR mice (Fig. 3B). Triglycerides and HDL cholesterol levels remained unchanged between both groups (data not shown). Serum LDL cholesterol was decreased in HF-DR mice at time point of section, which caused a significant increase in the HDL/LDL-cholesterol ratio in these mice (Fig. 3D).

\section{Gene expression in epididymal WAT was drastically altered between HF-DR and HF-AL mice}

Gene expression in epididymal WAT was measured after 12 weeks of HF-DR or HF-AL diet. Of the more than 43000 transcripts that were studied, 24146 transcripts were found to be expressed in WAT. After filtering the transcripts that encode for the same gene and are similarly regulated, 16995 genes appeared to be expressed in WAT (Fig. 4A), of which 8643 genes were significantly different expressed between HF-DR and 

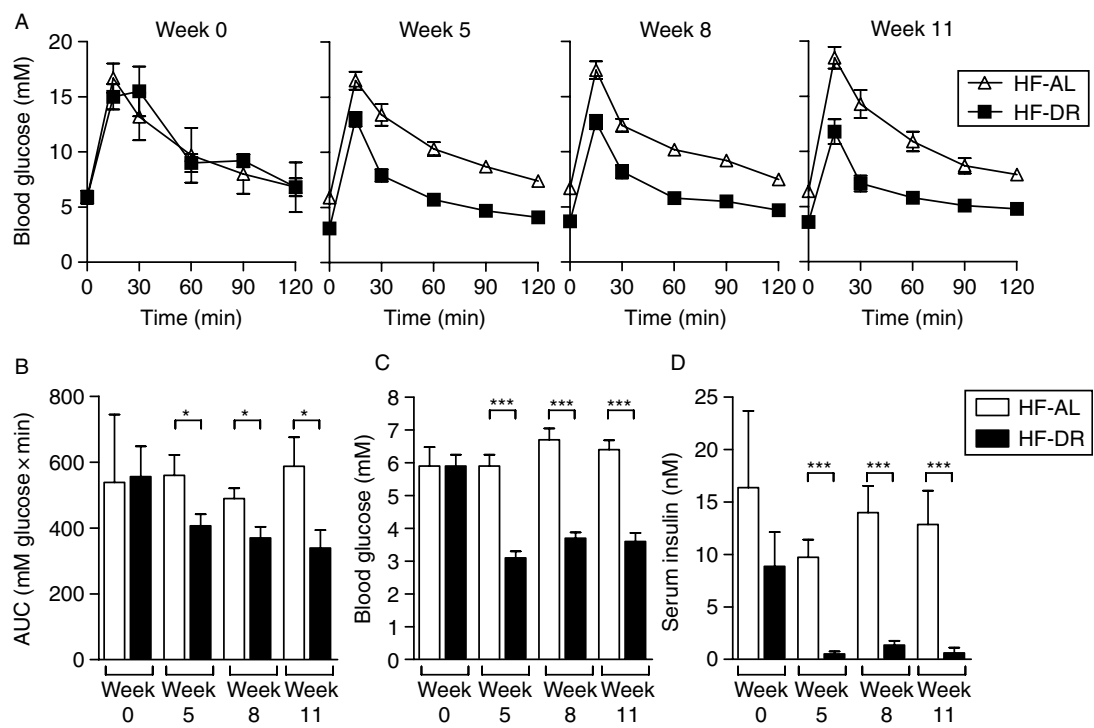

D

Figure 2 HF-DR improved glucose tolerance and decreased fasted glucose and insulin levels. (A) Oral glucose tolerance was tested at the start of the intervention and after 5, 8, and 11 weeks and improved during the course of the experiment. (B) 5, 8, and 11 weeks after the start of the restriction, HF-DR mice had increased glucose sensitivity, as measured by the incremental area under the curve. (C and D) At 5, 8, and 11 weeks, HF-DR mice exhibit a decrease in serum glucose and insulin levels. Data are mean \pm S.E.M. of 12 mice (results of the tests in week 0 are based on three mice per group). ${ }^{\star} P<0.05$; ${ }^{\star \star \star} P<0.001$.

HF-AL mice $(P<0 \cdot 01$ Benjamini-Hochberg FDR adjusted). Initially, we focused on the 96 genes that have a $P$ value $<10^{-11}$ (Table 3 ). The majority of these 96 genes is involved in lipid metabolism and mitochondrial function. A substantial part is involved in other metabolic processes (particularly in carbohydrate metabolism) and in the cellular response to stress (Fig. 5). In total, 24 genes have an unknown function. The 96 genes that were differentially expressed between HF-DR and HF-AL mice were not significantly modulated by $\mathrm{HF}$ feeding on itself, as analyzed between HF-AL and $t=0$ mice (Fig. 4B and C).

\section{Microarray analysis on highly significantly regulated genes revealed a major role for genes involved in lipid metabolism and mitochondrial functioning}

\section{Lipid metabolism}

A large proportion of the significantly regulated genes $\left(P<10^{-11}\right)$ play a role in lipid metabolism. All genes in this group exhibit a strong upregulation compared with the expression in HF-AL mice, except for BC005764 that serves a function in triglycerides formation and was downregulated. Among the upregulated genes in this group, sterol regulatory element-binding protein 2 (Srebf2) functions as a key transcriptional regulator of genes involved in fatty acid and cholesterol synthesis. The majority of the genes in this group is known to be under transcriptional control of Srebf2 (denoted with asterisks in Table 3). Indeed, all genes involved in cholesterol synthesis (Cyp51, Fdps, Hmgcr, Insig1, Lss, $M v d$, Sqle, and $T m 7 s f 2)$ and fatty acid synthesis and elongation (Acaca, Acly, Elovl3, Elovl6, and Pecr) were significantly upregulated as was $M e 1$ that plays a central role in adipose metabolism, linking gluconeogenesis and fatty acid metabolism by producing NADPH. This confirms earlier findings of long- and short-term DR, although on a low-fat diet (Higami et al. 2004, van Schothorst et al. 2006), but is in contrast with short-term HF-DR of only 12 days (van Schothorst et al. 2006). Interestingly, Sqle and Hmgcr are rate limiting enzymes in cholesterol synthesis, while Elovl6 controls the first, rate limiting condensation step of fatty acid elongation (Leonard et al. 2004). The transcription of Ppara and Pparg, two other key regulators of lipid metabolism, were not altered by the restriction regime (also see Table 4). HF-DR upregulated the expression of two genes encoding lipolysis-related proteins (Aspg, Lpcat3) and it upregulated the expression of two StAR-related lipid transfer proteins (Stard4, Stard5) that play a role in the transfer of cholesterol to different cellular compartments, such as the endoplasmic reticulum and the Golgi apparatus (Rodriguez-Agudo et al. 2008) and Rdh11 and Sorl1 that play a role in the reduction of short-chain (fatty) aldehydes and the uptake of lipoproteins and proteases respectively. 
A

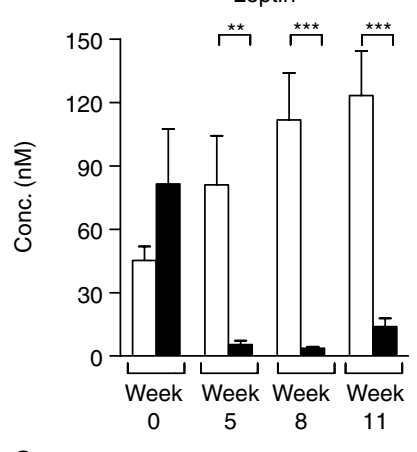

C

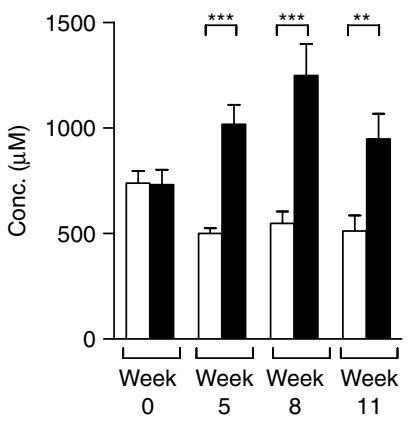

B Total cholesterol
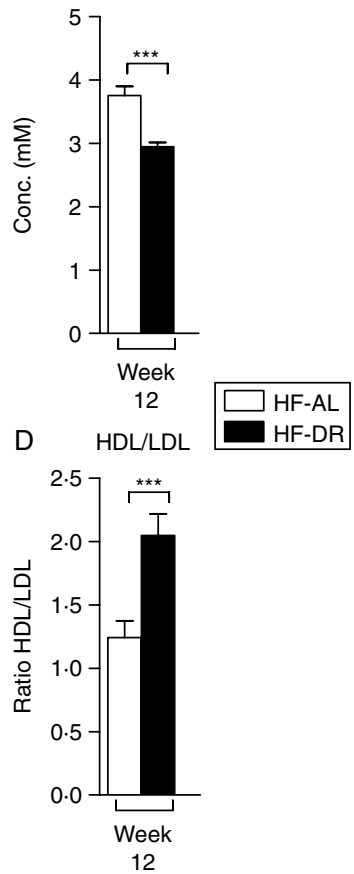

Figure 3 Fasting serum adipokine and cholesterol levels of HF-DR mice altered during dietary restriction. HF-DR mice exhibit decreased leptin (A) and total cholesterol (B) levels and increased adiponectin (C) levels. (D) The dietary intervention elevated the ratio of HDL-cholesterol to LDL-cholesterol in HF-DR animals. Fasting leptin and adiponectin concentrations were determined at the start of the intervention and 5, 8, and 11 weeks afterward. The level of cholesterol was determined at the end of the study. Data are mean \pm S.E.M. of 12 mice. ${ }^{\star \star} P<0 \cdot 01 ;{ }^{\star \star \star} P<0 \cdot 001$.

\section{Mitochondrial functioning}

All eight mitochondrial genes that were highly significantly regulated by HF-DR (with $P<10^{-11}$ ) seem to promote mitochondrial functioning and biogenesis, except for C80638, a mitochondrial sodium/hydrogen exchanger, of which transcription is downregulated by HF-DR. The majority of genes in this group fulfills a role in mitochondrial activity. Transcription of Fxn, for example, a gene that promotes mitochondrial function and oxidative phosphorylation, was increased by HF-DR. The same holds true for $L 2 h g d h$ and Slc25al that both play a promoting role in the mitochondrial citric acid cycle. Transcription of mitochondrial localized If $i 27$ protein that is expected to inhibit adipocyte differentiation and mitochondrial biogenesis and function ( $\mathrm{Li}$ et al. 2009) was downregulated.

Since the genes mentioned above are not known as the 'classical' regulators of mitochondrial functioning, we further analyzed the complete list of regulated genes $(P<0 \cdot 01)$ for genes that are better established as key regulators in mitochondrial biogenesis, dynamics, and autophagy (Table 4). Ppargc1a, Ppargc1b, Esrra, Nrf1, and Tfam, which are known to be of major importance for mitochondrial biogenesis (Scarpulla 2008), were indeed all upregulated in HF-DR animals. The same holds true for Dnm1l, Mtfr1, March5, Mfn1, Opa1, Oma1, and Stoml2, the genes that play an important role in mitochondrial fission and fusion (Yoon et al. 2010). Mtor, a transcription factor that is involved in the suppression of autophagy and cell death (Jung et al. 2010), is upregulated in HF-DR animals. Ulk2 promotes autophagy and cell death in the absence of Mtor and is consistently downregulated. The expression of Park2 that is involved in the induction of mitophagy and the promotion of cell survival (Narendra et al. 2008) is,
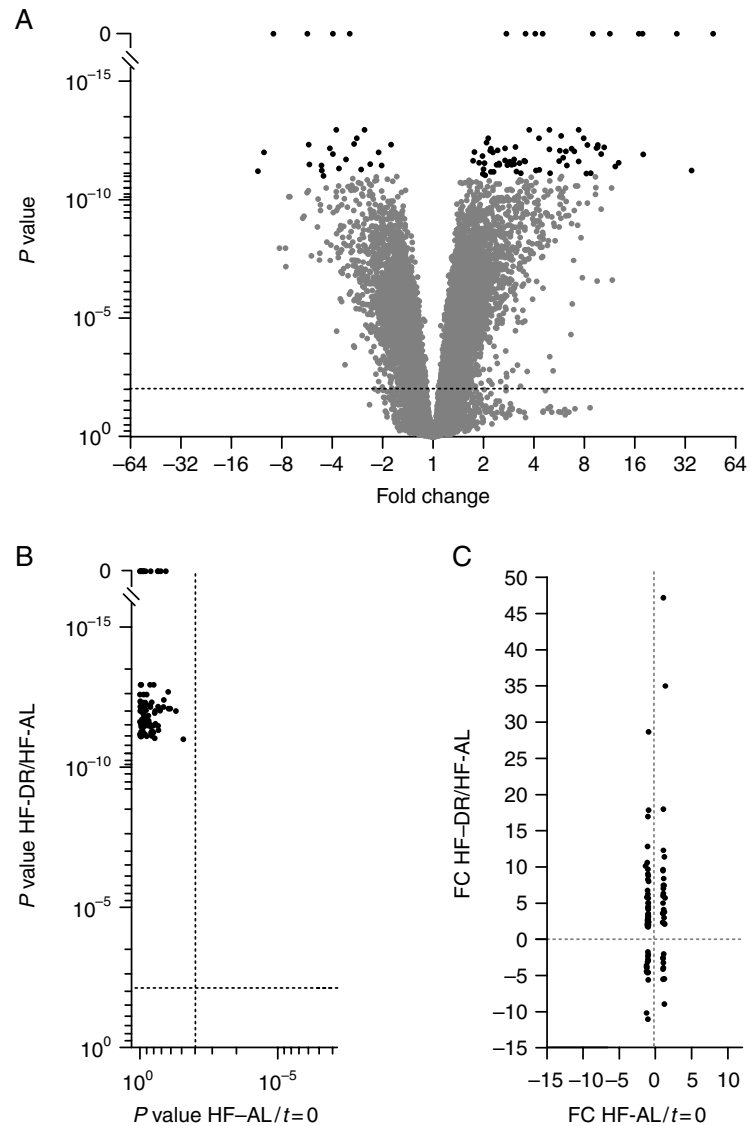

Figure 4 Volcano plot (A) of 16995 genes expressed in WAT showing the $t$-test statistics $P$ value plotted against the fold change of each transcript of the microarray analysis between HF-DR and HF-AL mice. $P$ values were corrected for multiple testing using a Benjamini-Hochberg correction. Black dots represent the 96 genes that have a $P$ value smaller than $10^{-11}$ The dotted line indicates the significance level of $0 \cdot 01$. (B and $C)$ The 96 genes that were differentially expressed between HF-DR and HF-AL mice as observed by microarray analysis were not modulated between HF-AL and $t=0$ mice (based on $P$ values of the HF-DR and HF-AL compared to HF-AL and $t=0$ mice (the dotted lines indicate a significance level of 0.01 ) and based on fold changes (FC) of HF-DR and HF-AL compared to HF-AL and $t=0$ mice). 
Table 3 Categorization and expression profiles of strongly regulated genes $\left(P<10^{-11}\right)$ between HF-AL and HF-DR mice. Genes are ordered based on function and within functional categories based on alphabetic order. Genes indicated with an asterisk are transcriptionally regulated by Srebf2

\section{Gene}

symbols

Lipid metabolism

Fdps

$\mathrm{HmgCr}^{*}$

Insig1

Lss

Mvd

Sqle*

Tm7sf2

BC005764

Elov/3

Elovi6 ${ }^{\star}$

$\mathrm{Pecr}$

Acaca*

Acly*

Aspg

Lpcat3

Rdh11*

Srebf2

Stard $4^{\star}$

Stard5

Sorl1*

Sortilin-related receptor

Mitochondrial function

1700020C11 Rik Mitochondrial 18 kDa protein

$\begin{array}{ll}\text { C80638 } & \text { Mitochondrial sodium/hydrogen exchanger } \\ \text { Fxn } & \text { Frataxin, mitochondrial } \\ \text { Ifi27 } & \text { Interferon, } \alpha \text {-inducible protein } 27 \text { like 2A } \\ \text { L2hgdh } & \text { L-2-hydroxyglutarate dehydrogenase } \\ \text { Ppif } & \text { Peptidyl-prolyl cis-trans isomerase, mitochondrial } \\ \text { Slc25a1 } & \begin{array}{c}\text { Solute carrier family 25 (mitochondrial citrate } \\ \text { transporter), member 1 }\end{array} \\ \text { Timm9 } & \begin{array}{c}\text { Translocase of inner mitochondrial membrane } \\ 9 \text { homolog transcript variant 1 }\end{array}\end{array}$

Other metabolic genes

$\begin{array}{ll}\text { Acp1 } & \text { Acid phosphatase 1 } \\ \text { Adh1 } & \text { Alcohol dehydrogenase 1 } \\ \text { Me1 } & \text { NADP-dependent malic enzyme } \\ \text { Pdk1 } & \text { Pyruvate dehydrogenase kinase isozyme 1 } \\ \text { Pgk1 } & \text { Phosphoglycerate kinase 1 } \\ \text { Pgp } & \text { Phosphoglycolate phosphatase } \\ \text { Ppp1r3b } & \text { Protein phosphatase 1 regulatory subunit 3B } \\ \text { Prei4 } & \text { Putative glycerophosphodiester phosphodiesterase } \\ \text { Psph } & \text { Phosphoserine phosphatase } \\ \text { Rorc } & \text { Nuclear receptor ROR- } \gamma\end{array}$$$
-5
$$$$
2 \cdot 4
$$$$
9 \cdot 0
$$$$
\begin{aligned}
& 5 \cdot 0 \\
& 2 \cdot 8
\end{aligned}
$$$$
2 \cdot 1
$$$$
17 \cdot 8
$$$$
2 \cdot 7
$$$$
5 \cdot 0
$$$$
5 \cdot 7
$$

Cytochrome P450, family 51

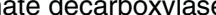

$2.50 \times 10^{-13}$ $2.50 \times 10^{-13}$

$2.40 \times 10^{-12}$

$7.50 \times 10^{-12}$

$7.00 \times 10^{-13}$

$4.90 \times 10^{-13}$

$1.10 \times 10^{-13}$

$7.50 \times 10^{-12}$

$2.50 \times 10^{-13}$

0

0

$3.50 \times 10^{-12}$

$2.30 \times 10^{-12}$

$3.90 \times 10^{-12}$

$2.70 \times 10^{-12}$

$2.10 \times 10^{-12}$

$6 \cdot 10 \times 10^{-13}$

$2.0 \quad 7.90 \times 10^{-12}$

$2.1 \quad 3.80 \times 10^{-13}$

$3.3 \quad 2.80 \times 10^{-12}$

$6.29 .10 \times 10^{-13}$

$6 \cdot 3 \quad 3.56 \times 10^{-12}$

$\begin{array}{ll}-9.0 & 0\end{array}$

$2.3 \quad 6.58 \times 10^{-12}$

$-11 \cdot 1 \quad 6 \cdot 15 \times 10^{-12}$

$2.0 \quad 2.77 \times 10^{-12}$

$3.2 \quad 6.42 \times 10^{-12}$

$8.2 \quad 7.59 \times 10^{-12}$

$3.1 \quad 5.83 \times 10^{-13}$

0

$3.30 \times 10^{-12}$ 0

$1 \cdot 12 \times 10^{-13}$

$9.36 \times 10^{-13}$

$2.51 \times 10^{-13}$

0

$6 \cdot 70 \times 10^{-13}$

$7 \cdot 31 \times 10^{-13}$

$5.7 \quad 8.49 \times 10^{-13}$
Function

Cholesterol synthesis

Cholesterol synthesis

Cholesterol synthesis

Cholesterol synthesis

Cholesterol synthesis

Cholesterol synthesis

Cholesterol synthesis

Cholesterol synthesis

1,2-diacylglycerol synthesis

Fatty acid elongation

Fatty acid elongation

Fatty acid elongation

Fatty acid synthesis

Lipogenesis

Lipolysis

Lipolysis

Reduction of short-chain aldehydes

Transcriptional regulation of lipid metabolism

Intracellular transport of cholesterol

Intracellular transport of cholesterol

Uptake of lipoproteins and proteases

Maintenance of the mitochondrial network

$\mathrm{H}^{+} / \mathrm{Na}^{+}$exchange across mitochondrial inner membrane

Mitochondrial iron transport and respiration

Adipocyte differentiation and mitochondrial biogenesis

Synthesis of 2-oxoglutarate/ Krebs cycle

Inhibition of the mitochondrial permeability transition pore

Citrate transport/Krebs cycle

Import and insertion of mitochondrial inner membrane proteins

Amino acid dephosphorylation (by similarity)

Alcohol metabolism

Gluconeogenesis

Gluconeogenesis

Glycolysis

Carbohydrate metabolic process

Glycogen synthesis

Carbohydrate/glycerol metabolic process

Amino acid biosynthesis (by similarity)

Transcriptional regulation of metabolism

(continued) 
Table 3 Continued

\begin{tabular}{|c|c|c|c|c|}
\hline $\begin{array}{l}\text { Gene } \\
\text { symbols }\end{array}$ & Protein name & FC & $P$ value & Function \\
\hline Slc2a5 & $\begin{array}{l}\text { Solute carrier family } 2 \text { (facilitated glucose } \\
\text { transporter), member } 5\end{array}$ & $35 \cdot 0$ & $5.69 \times 10^{-12}$ & Glucose uptake \\
\hline \multicolumn{5}{|c|}{ Cellular response to stress } \\
\hline Blcap & Bladder cancer-related protein & $-4 \cdot 5$ & $9 \cdot 77 \times 10^{-12}$ & $\begin{array}{l}\text { Regulation of cell proliferation } \\
\text { and apoptosis (by similarity) }\end{array}$ \\
\hline $\mathrm{C} 8 \mathrm{~g}$ & Complement component $8, \gamma$-subunit & $2 \cdot 5$ & $3.26 \times 10^{-12}$ & $\begin{array}{l}\text { Complement pathway } \\
\text { (by similarity) }\end{array}$ \\
\hline Egln3 & EGL nine homolog 3 & $7 \cdot 4$ & $2.36 \times 10^{-12}$ & $\begin{array}{l}\text { Cellular response to stress } \\
\text { (by similarity) }\end{array}$ \\
\hline Fastkd3 & FAST kinase domains 3 & $2 \cdot 2$ & $6.59 \times 10^{-12}$ & $\begin{array}{l}\text { Regulation of apoptosis } \\
\text { (by similarity) }\end{array}$ \\
\hline Gclm & Glutamate-cysteine ligase regulatory subunit & $2 \cdot 2$ & $8.49 \times 10^{-13}$ & $\begin{array}{l}\text { Glutathione metabolism; } \\
\text { response to oxidative stress }\end{array}$ \\
\hline Klf11 & Krueppel-like factor 11 & $-1 \cdot 8$ & $4.69 \times 10^{-13}$ & $\begin{array}{l}\text { Transcriptional regulation of } \\
\text { apoptosis }\end{array}$ \\
\hline Tmem49 & Transmembrane protein 49 & $2 \cdot 1$ & $9 \cdot 10 \times 10^{-12}$ & $\begin{array}{l}\text { Cellular response to stress } \\
\text { (by similarity) }\end{array}$ \\
\hline Traf4 & Tnf receptor associated factor 4 & 6 & $1.68 \times 10^{-12}$ & Proapoptotic cellular signaling \\
\hline \multicolumn{5}{|l|}{ Other functions } \\
\hline$A b c c 3$ & ATP-binding cassette, sub-family C & $-3 \cdot 0$ & $4.35 \times 10^{-13}$ & $\begin{array}{l}\text { Transmembrane organic anion } \\
\text { transport }\end{array}$ \\
\hline Ank & Progressive ankylosis & $4 \cdot 3$ & $5.29 \times 10^{-12}$ & $\begin{array}{l}\text { Transmembrane inorganic } \\
\text { pyrophosphate transport }\end{array}$ \\
\hline Atp1a3 & $\mathrm{Na}^{+} / \mathrm{K}^{+}$-transporting ATPase subunit $\alpha-3$ & $16 \cdot 9$ & 0 & Transmembrane ion transport \\
\hline Anxa6 & Annexin A6 & $-2 \cdot 6$ & $1 \cdot 12 \times 10^{-13}$ & Transmembrane ion release \\
\hline Kcne1I & $\begin{array}{l}\mathrm{K}^{+} \text {voltage-gated channel, Isk-related family, } \\
\text { member 1-like }\end{array}$ & $-4 \cdot 6$ & $3.52 \times 10^{-12}$ & Transmembrane ion release \\
\hline Kctd15 & $\mathrm{K}^{+}$channel tetramerization domain containing 15 & $-2 \cdot 4$ & $3.13 \times 10^{-12}$ & Transmembrane ion release \\
\hline Bmper & BMP-binding endothelial regulator & $-3 \cdot 3$ & $1.95 \times 10^{-12}$ & Cell differentiation \\
\hline Col1a1 & Collagen $\alpha-1(\mathrm{I})$ chain & -3.9 & $8.00 \times 10^{-13}$ & Cell development \\
\hline Cry1 & Cryptochrome 1 (photolyase-like) & $3 \cdot 6$ & 0 & $\begin{array}{l}\text { Regulation of the circadian } \\
\text { rhythm }\end{array}$ \\
\hline Dixdc1 & DIX domain containing 1 & $3 \cdot 1$ & $1.94 \times 10^{-12}$ & $\begin{array}{l}\text { Multicellular organismal } \\
\text { development }\end{array}$ \\
\hline Dock11 & Dedicator of cytokinesis 11 & $-4 \cdot 6$ & $5.69 \times 10^{-12}$ & Activation of $\mathrm{G}$ proteins \\
\hline lft122 & Intraflagellar transport 122 homolog & $-2 \cdot 7$ & $5 \cdot 14 \times 10^{-12}$ & Cilia formation \\
\hline Nnat & Neuronatin, transcript variant 1 & $-4 \cdot 0$ & 0 & $\begin{array}{l}\text { Regulation of insulin secretion } \\
\text { (in neurons and pancreas) }\end{array}$ \\
\hline Pcsk4 & Proprotein convertase subtilisin/kexin type 4 & $5 \cdot 8$ & $1.99 \times 10^{-13}$ & $\begin{array}{l}\text { Conversion of secretory } \\
\text { precursor proteins }\end{array}$ \\
\hline Recql4 & RecQ protein-like 4 & $9 \cdot 7$ & $4.87 \times 10^{-13}$ & DNA recombination \\
\hline$S 100 b$ & S100 protein, $\beta$-polypeptide & $-4 \cdot 0$ & $1.17 \times 10^{-12}$ & $\begin{array}{l}\text { Regulation of proinflammatory } \\
\text { cytokines (in neurons) }\end{array}$ \\
\hline Sar1b & SAR1 gene homolog B & $2 \cdot 0$ & $1.43 \times 10^{-12}$ & Protein transport from ER to Golgi \\
\hline Syngr1 & Synaptogyrin 1 , transcript variant $1 b$ & 3.0 & $3.30 \times 10^{-12}$ & $\begin{array}{l}\text { Protein targeting for synaptic } \\
\text { like microvesicles }\end{array}$ \\
\hline Tmem41b & Transmembrane protein 41B & $2 \cdot 4$ & $9 \cdot 71 \times 10^{-13}$ & Transmembrane protein \\
\hline Tmem79 & Transmembrane protein 79 & $4 \cdot 5$ & 0 & Transmembrane protein \\
\hline Polr3g & Polymerase (RNA) III (DNA directed) polypeptide G & $4 \cdot 1$ & 0 & (Regulation of) transcription \\
\hline 1500003022 Rik & $\begin{array}{l}\text { Ribosomal RNA processing 8, methyltransferase, } \\
\text { homolog }\end{array}$ & 1.9 & $2 \cdot 74 \times 10^{-12}$ & Regulation of transcription \\
\hline Zbtb20 & Zinc finger and BTB domain containing 20 & $-2 \cdot 0$ & $3.56 \times 10^{-12}$ & Regulation of transcription \\
\hline 6330548G22 Rik & Small nuclear ribonucleoprotein 35 & $1 \cdot 7$ & $2 \cdot 21 \times 10^{-12}$ & RNA splicing \\
\hline
\end{tabular}

however, increased in these animals; the same holds true for the expression of Rab7 and Bnip $3 l$ that are involved in the induction of autophagy (Jager et al. 2004, Zhang \& Ney 2009).

\section{Other metabolic genes}

Next to the genes involved in lipid metabolism and mitochondrial function, we found a number of genes that are involved in other metabolic processes. Most of 


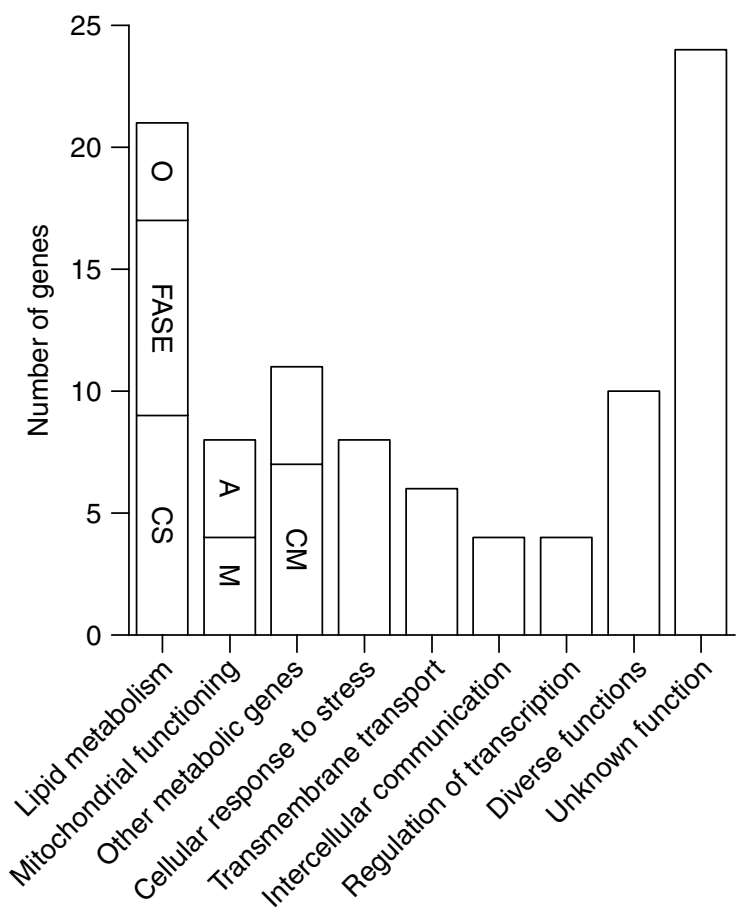

Figure 5 Categorization of the 96 genes that were found to be strongly regulated $\left(P\right.$ value $<10^{-11}$ ) between HF-DR and HF-AL mice into functional categories. The majority of genes is involved in lipid metabolism and mitochondrial functioning. Nine genes are involved in cholesterol synthesis (CS), eight are involved in fatty acid synthesis and elongation (FASE), and four genes are involved in other processes in lipid metabolism (O). Four genes are involved in mitochondrial maintenance $(M)$ and four genes are involved in mitochondrial activity (A). Most of the genes involved in other metabolic processes serve a role in carbohydrate metabolism (CM).

the genes in this category are involved in carbohydrate metabolism. Pdk1, for example, inhibits glycolysis and was strongly upregulated by the restriction regime. Similarly, Ppp1r3b promoting glycogen synthesis and Slc2a5 promoting glucose uptake are both increased in HF-DR animals.

\section{Pathway analysis}

In addition to analysis of strongly significantly regulated genes, we performed a pathway analysis on the complete set of regulated genes (Table 5). This analysis confirmed that the primary changes in gene expression are related to lipid metabolism and mitochondrial functioning. Of the top ten named pathways, eight pathways (oxidative phosphorylation, cholesterol biosynthesis, citric acid cycle (ubiquinone metabolism), regulation of lipid metabolism, mitochondrial fatty acid unsaturated and long chain $\beta$-oxidation, and regulation of fatty acid metabolism) are involved in these functions.

\section{Microarray results were confirmed with qRT-PCR}

qRT-PCR was used to validate the microarray results for seven genes with an important role in lipid metabolism. This resulted in a significant upregulation of all seven genes with fold changes ranging between 4.0 and 513.3 (microarray data ranged between $2 \cdot 0$ and $48 \cdot 0$ for these genes) (Fig. 6).

\section{HF-DR mice have higher levels of mitochondrial mass in WAT}

Mitochondrial and nuclear DNA content in WAT of HF-AL, HF-DR, and $t=0$ mice was compared with qRT-PCR in order to estimate mitochondrial density. HF-DR mice had a significantly higher mitochondrial DNA content compared with both HF-AL and $t=0$ mice (Fig. 7). HF feeding (HF-AL versus $t=0$ ) reduced mitochondrial density, although non-significantly.

\section{Discussion}

\section{DR of a HF diet improves metabolic health and promotes a metabolic adaptation toward lipid metabolism}

We demonstrate that DR of a HF diet restores glucose sensitivity, increases the mitochondrial density in WAT, decreases the serum levels of cholesterol and leptin, and increases serum adiponectin levels. The bodyweight and serum parameters of HF-DR mice remained stable during the last 7 weeks of restriction, implying that within 5 weeks, HF-DR mice have adapted to the restriction regime and exhibit a steady energy balance. The beneficial effects on health are comparable to previous reports that demonstrate that DR on a standard mouse diet improves health, by enhancing insulin sensitivity (Dhahbi et al. 2001); decreasing serum cholesterol (Choi et al. 1988), glucose, and leptin levels (Reimer et al. 2010); and increasing serum adiponectin (Combs et al. 2003). To our knowledge, this is the first study that exclusively reports improvements in markers of the metabolic syndrome by DR with a HF diet. Two previous studies, in fact, reported unfavorable effects in mice that were pair-fed on a HF diet to match the caloric intake of mice on a low-fat diet. A certain iso-caloric treatment was found to result in a decrease in insulin sensitivity in the restricted HF group (Petro et al. 2004), whereas a second study reported that HF pair-fed mice develop insulin resistance, hepatic steatosis, and obesity (de Meijer et al. 2010). The diets used in both studies, however, contained almost twice as much energy available from fat compared with the diet we used in our study (58 and $60 \%$ energy from fat, compared with $30 \%$ ), which might have evoked a different coping strategy. A third study on HF-DR in mice, consistently, 
Table 4 Expression profiles of genes that are known to play an important role in mitochondrial function. Genes are ordered based on function and within functional category based on alphabetic order. Genes indicated with an asterisk are significantly differently expressed between HF-DR and HF-AL mice

\begin{tabular}{|c|c|c|c|c|}
\hline $\begin{array}{l}\text { Gene } \\
\text { symbols }\end{array}$ & Gene name & FC & $P$ value & Function \\
\hline \multicolumn{5}{|c|}{ Mitochondrial biogenesis } \\
\hline$C o \times 5 b^{*}$ & Cytochrome $c$ oxidase, subunit $\mathrm{Vb}$ & $2 \cdot 10$ & $5.36 \times 10^{-7}$ & Formation of respiratory chain complex IV \\
\hline Esrra* $^{\star}$ & Estrogen related receptor, $\alpha$ & $2 \cdot 06$ & $1.64 \times 10^{-6}$ & $\begin{array}{l}\text { Regulation of nuclear and mitochondrial } \\
\text { respiratory proteins }\end{array}$ \\
\hline$N r f 1^{*}$ & Nuclear respiratory factor 1 & $1 \cdot 25$ & $7 \cdot 68 \times 10^{-4}$ & $\begin{array}{l}\text { Regulation of nuclear and mitochondrial } \\
\text { respiratory proteins }\end{array}$ \\
\hline Polg & Polymerase (DNA directed), $\gamma$ & -1.06 & $2 \cdot 85 \times 10^{-1}$ & mtDNA maintenance \\
\hline Ppara & Peroxisome proliferator-activated receptor $\alpha$ & $-1 \cdot 19$ & $2.44 \times 10^{-2}$ & Regulation of fatty acid oxidation \\
\hline Pparg & Peroxisome proliferator-activated receptor $\gamma$ & $-1 \cdot 13$ & $4.09 \times 10^{-1}$ & Regulation of fatty acid oxidation \\
\hline Ppargc1a* & $\begin{array}{l}\text { Peroxisome proliferative-activated receptor, } \gamma \text {, } \\
\text { coactivator } 1 \alpha\end{array}$ & $2 \cdot 39$ & $2 \cdot 13 \times 10^{-6}$ & Regulation of mitochondrial biogenesis \\
\hline Sirt3 & Sirtuin 3 & $1 \cdot 10$ & $1 \cdot 78 \times 10^{-1}$ & $\begin{array}{l}\text { ROS detoxification + mitochondrial } \\
\text { biogenesis }\end{array}$ \\
\hline $\operatorname{Tfam}^{\star}$ & Transcription factor A, mitochondrial & $1 \cdot 34$ & $9 \cdot 71 \times 10^{-6}$ & $\begin{array}{l}\text { Stabilization + maintenance of the } \\
\text { mitochondrial chromosome }\end{array}$ \\
\hline \multicolumn{5}{|c|}{ Mitochondrial dynamics } \\
\hline Dhodh* & Dihydroorotate dehydrogenase & $1 \cdot 37$ & $6.65 \times 10^{-7}$ & Regulation of mitochondrial fission \\
\hline$D n m 1 I^{*}$ & Dynamin 1-like & $1 \cdot 32$ & $3.46 \times 10^{-6}$ & Mitochondrial fission \\
\hline Fis1 & Fission 1 & $1 \cdot 16$ & $3.58 \times 10^{-2}$ & Mitochondrial fission \\
\hline Gdap1/1 & $\begin{array}{l}\text { Ganglioside-induced differentiation-associated } \\
\text { protein 1-like } 1\end{array}$ & $-1 \cdot 14$ & $1.46 \times 10^{-1}$ & Mitochondrial fission \\
\hline Mtfr $1^{*}$ & Mitochondrial fission regulator 1 & 1.69 & $2.02 \times 10^{-8}$ & Mitochondrial fission \\
\hline 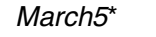 & Membrane-associated ring finger $(\mathrm{C} 3 \mathrm{HC} 4) 5$ & $1 \cdot 65$ & $4.76 \times 10^{-6}$ & Activation of Dnm1l, Fis1, and Mfn2 \\
\hline Mfn $^{\star}$ & Mitofusin 1 & $1 \cdot 22$ & $4.70 \times 10^{-4}$ & Outer membrane fusion \\
\hline $\mathrm{Bcl} 2$ & B-cell leukemia/lymphoma 2 & $-1 \cdot 73$ & $2.97 \times 10^{-8}$ & Inhibition of autophagy \\
\hline Bnip3 & BCL2/adenovirus E1B interacting protein 3 & -1.06 & $6.54 \times 10^{-1}$ & $\begin{array}{l}\text { Induction of autophagy, cell death, } \\
\text { and mitophagy }\end{array}$ \\
\hline Bnip3/ & BCL2/adenovirus E1B interacting protein 3-like & $1 \cdot 53$ & $1 \cdot 28 \times 10^{-5}$ & $\begin{array}{l}\text { Induction of autophagy, cell death, } \\
\text { and mitophagy }\end{array}$ \\
\hline Mtor ${ }^{*}$ & Mechanistic target of rapamycin & $1 \cdot 34$ & $7 \cdot 23 \times 10^{-5}$ & Regulation of autophagy \\
\hline$R a b 7^{*}$ & RAB7, member RAS oncogene family & $1 \cdot 31$ & $4.67 \times 10^{-5}$ & Maturation of autophagic vacuoles \\
\hline Ulk1 & Unc-51-like kinase 1 & $1 \cdot 10$ & $1.79 \times 10^{-1}$ & Induction of autophagy \\
\hline Ulk2* & Unc-51-like kinase 2 & $-1 \cdot 82$ & $2 \cdot 73 \times 10^{-9}$ & Induction of autophagy \\
\hline Park2* & Parkin 2 & $1 \cdot 44$ & $2.79 \times 10^{-3}$ & Induction of mitophagy \\
\hline Pink1 & PTEN-induced putative kinase 1 & $-1 \cdot 12$ & $1.81 \times 10^{-1}$ & Induction of mitophagy \\
\hline
\end{tabular}

reported decreased fasting insulin levels; although it also reported a decrease in serum adiponectin levels and only minor effects of HF restriction on inflammations in WAT (Kalupahana et al. 2011). An important difference with our study is that the authors used a run-in period on the HF diet that is much longer than the actual restriction period. In this case, 2 months of DR might simply be insufficient to reverse the negative effects of 6 months HF feeding ad libitum and to stabilize energy balance as was seen in our study. The occurrence of beneficial effects of DR with a HF diet seems, consequently, to depend on both the duration of restriction and the fat content of the diet.

To additionally examine the molecular events associated with the observed adaptation to HF-DR, we analyzed whole genome expression in WAT, the organ 
Table 5 Top ten pathways that are significantly regulated between HF-AL and HF-DR mice. Pathway analysis was performed on the complete set of regulated genes $(P<0.01)$. The top ten pathways (based on $P$ value) consist of several pathways involved in lipid metabolism and mitochondrial function. The table additionally shows the total number of genes that is involved in the pathway and the number of these genes that was either upregulated or downregulated in our dataset

\begin{tabular}{|c|c|c|c|c|}
\hline Pathway & $P$ value & $\begin{array}{l}\text { Total number of } \\
\text { genes involved } \\
\text { in pathway }\end{array}$ & $\begin{array}{l}\text { Number of } \\
\text { upregulated genes } \\
\text { in dataset }\end{array}$ & $\begin{array}{l}\text { Number of } \\
\text { downregulated } \\
\text { genes in dataset }\end{array}$ \\
\hline 1. Oxidative phosphorylation & $1.80 \times 10^{-11}$ & 114 & 77 & 0 \\
\hline 2. Cholesterol biosynthesis & $1.16 \times 10^{-6}$ & 22 & 20 & 0 \\
\hline 3. Citric acid cycle & $2.49 \times 10^{-6}$ & 20 & 18 & 1 \\
\hline $\begin{array}{l}\text { 4. Regulation of lipid metabolism } \\
\text { via } L X R, N F-Y \text {, and SREBF }\end{array}$ & $7 \cdot 75 \times 10^{-6}$ & 35 & 18 & 9 \\
\hline 5. Ubiquinone metabolism & $1.03 \times 10^{-5}$ & 52 & 37 & 0 \\
\hline 6. BAD phosphorylation & $1.08 \times 10^{-5}$ & 88 & 29 & 12 \\
\hline $\begin{array}{l}\text { 7. Mitochondrial long-chain fatty acid } \\
\beta \text {-oxidation }\end{array}$ & $1 \cdot 14 \times 10^{-5}$ & 18 & 14 & 2 \\
\hline 8. EDG3 signaling & $3.11 \times 10^{-5}$ & 68 & 13 & 22 \\
\hline $\begin{array}{l}\text { 9. Insulin regulation of fatty acid } \\
\text { metabolism }\end{array}$ & $5 \cdot 12 \times 10^{-5}$ & 55 & 25 & 9 \\
\hline $\begin{array}{l}\text { 10. Mitochondrial unsaturated fatty } \\
\text { acid } \beta \text {-oxidation }\end{array}$ & $5 \cdot 13 \times 10^{-5}$ & 16 & 13 & 1 \\
\hline
\end{tabular}

that was notably affected by HF-DR (Figs 1B, C and $3 \mathrm{~A}, \mathrm{C})$ and is known to play an important role in the development of metabolic complications in obesity (Trayhurn \& Beattie 2001). Among the drastic shifts in gene expression in WAT, the changes in genes involved in lipid metabolism and mitochondrial function were most pronounced (Table 3 and Fig. 5). In our study, the majority of lipid metabolism-related genes plays a role in cholesterol synthesis and fatty acid synthesis and elongation and was upregulated by the restriction regime. For this analysis, we initially focused on the functional interpretation of genes with the strongest $P$ values. To further validate this approach, we also conducted a pathway analysis on the complete set of regulated genes, which revealed significant regulation of several pathways involved in both lipid metabolism and mitochondrial function (Table 5), which further supports the functional interpretation of our initial approach. To our surprise, pathway analysis also pointed toward an upregulation of mitochondrial fatty acid oxidation, a result that seems contradictory to the observed increase in fatty acid synthesis and elongation. Earlier studies to the effects of DR on gene expression in WAT, however, also reported changes in genes and pathways involved in both storage and usage of energy; although in these studies, a standard rodent diet was used for DR and compared to our results, the effects on lipid metabolism are less pronounced (Higami et al. 2004, Park \& Prolla 2005). We propose that the HF-DR mice have developed an enhanced substrate efficiency for the abundant fat component in the diet and that upregulation of both fat storage and release pathways relates to the beneficial effects on metabolic health we observed in this study.
As both groups of mice were kept under the same rearing conditions and on diets with equal vitamin and mineral intake and identical macronutrient composition, most plausible alternative explanations for the differences in gene expression between HF-DR and
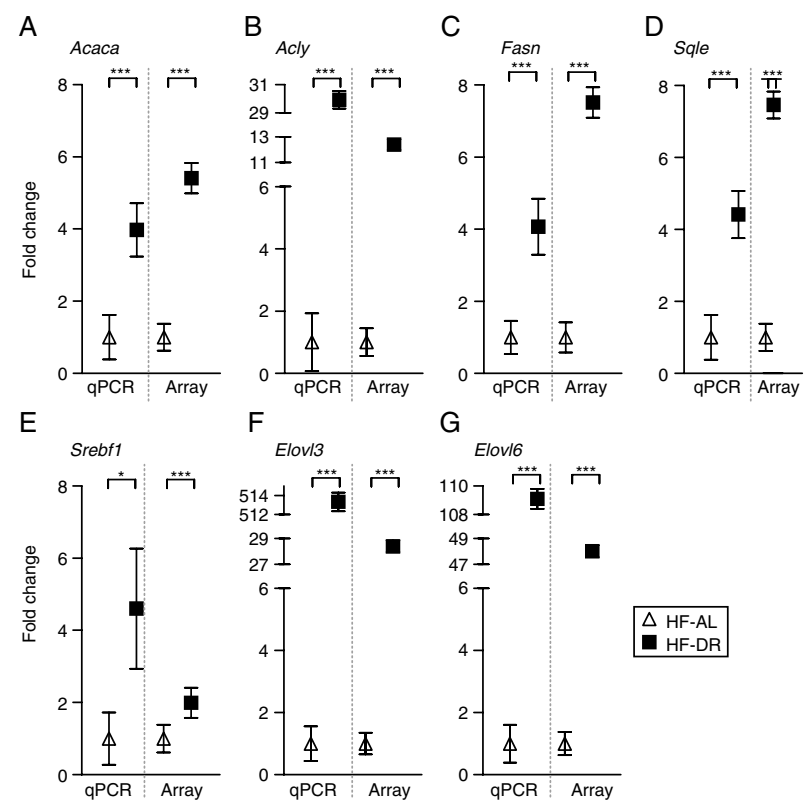

Figure 6 Confirmation of microarray results by real-time qRTPCR. The expression of (A) Acaca, (B) Acly, (C) Fasn, (D) Sqle, (E) Srebf1, (F) Elovl3, and (G) Elovl6 in HF-DR and HF-AL mice was analyzed by qRT-PCR (left) using stable reference genes Canx, B2m, Sil1, and Rps15. Data obtained with microarray are shown for comparison (right). Data represent the mean \pm S.E.M. of 12 mice, in which the mean expression of HF-AL mice is set to 1.0 . ${ }^{\star} P<0.05$; ${ }^{\star \star *} P<0.001$. 


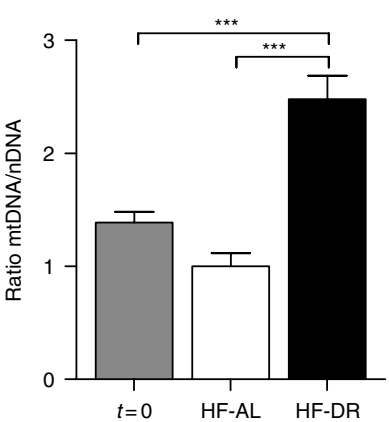

Figure 7 Mitochondrial density in WAT of $t=0, \mathrm{HF}-\mathrm{AL}$, and HF-DR mice, as measured by the mitochondrial DNA copy number versus nuclear DNA and measured with qRT-PCR. Data represent the mean \pm S.E.M. of 12 mice, of which the $\mathrm{mtDNA} / \mathrm{nDNA}$ ratio of HF-AL mice was set to $1 \cdot 0 .{ }^{* \star \star} P<0.001$.

HF-AL can be excluded. It should, nonetheless, be noted that, in order to match the levels of food intake, animals of both groups were treated differently. HF-DR animals received their restricted amount of food at the start of the light phase and were sectioned $6 \mathrm{~h}$ afterward, whereas HF-AL animals were sectioned $3 \mathrm{~h}$ after start of the light phase, which might have influenced expression patterns of genes that display a diurnal pattern, such as Bmal, Cry1, Elovl3, and Elovl6. Indeed, we found a significant upregulation of the circadian clock regulator Bmal in HF-DR mice (data not shown). However, we found the expression of Cry 1 to be increased, while it is expected to be stable within the time frame just mentioned (Ando et al. 2005). Accordingly, the expression level of Elovl3 is increased instead of decreased, as would be expected if the difference was due to the circadian rhythm of this gene (Anzulovich et al. 2006). Finally, the increase in expression of Elovl6 is well beyond the increase in expression that is normally seen during this time frame in the light phase (a twofold increase that is normally seen compared with a $47 \cdot 2$-fold increase observed in this study) (Cretenet et al. 2010). It seems, therefore, unlikely that the differences observed in the expression of metabolic genes, which is the focus of this study, are primarily due to the differences in feeding and sectioning time.

\section{Srebf1 and Srebf2 are expected to play a major role in the adaptation to a HF diet in HF-DR animals}

Srebf1 and -2 play an important role in the regulation of lipid metabolism and both were highly expressed in HF-DR mice. Although Srebf1 did not belong to the list of genes with the strongest $P$ values (Table 3), the same list contains various genes that are under transcriptional control of both Srebf isoforms, such as Elovl6, Acly, and Acaca (Matsuzaka et al. 2002). SREBPs (the human annotation of Srebfs) are known as crucial cellular molecules that mediate adaptive metabolic responses to changing dietary exposures (Strable \& Ntambi 2010). Nuclear translocation of SREBPs is regulated by intracellular fatty acid and sterol levels. When cellular sterols are abundant, SREBPs are inactive in the endoplasmic reticulum membrane. On sterol depletion, SREBPs are cleaved by regulated proteolysis to release the mature transcription factor domain, which translocates to the nucleus. SREBPs then bind promoter sterol regulatory elements (SREs) to activate genes involved in the biosynthesis and uptake of cholesterol and fatty acids (Brown \& Goldstein 1997). The expression of Ppara and Pparg, two other key regulators of lipid metabolism, is not significantly altered between HF-DR and HF-AL, implying the significance of both Srebfs in upregulating lipid metabolism in our study.

Consistent to the upregulation of both Srebfs, cholesterol synthesis appeared to be significantly changed in HF-DR mice (Fig. 5); in fact, 20 of the 22 genes that are involved in this metabolic process were upregulated by our treatment. At first sight, it might appear strange for HF-DR mice to increase the rate of cholesterol and fatty acid synthesis. The HF-AL mice consumed $3.94 \mathrm{kcal}$ from fat per day; this was $2.76 \mathrm{kcal}$ for HF-DR mice, whereas a chow-fed mouse eats about $1.08 \mathrm{kcal}$ from fat per day (Champy et al. 2008). Secondly, mice on a standard chow diet receive no cholesterol, whereas HF-DR mice do consume cholesterol, although to a lesser extent compared with HF-AL mice. It can, therefore, be assumed that both HF-DR and HF-AL mice received enough energy from fat. Similar results on Srebfs functioning and upregulation of energy metabolism have, however, earlier been observed in dietary restricted animals. At first, HF diets are known to induce expression of Srebf1 in the liver (Lin et al. 2005), and studies on both mice and humans showed that the expression of SREBPs is downregulated in obese versus lean subjects (Nadler et al. 2000, Soukas et al. 2000, Oberkofler et al. 2002). These authors subsequently hypothesize that the downregulation of Srebfs correlates with the dedifferentiation of adipocytes in obesity, while enhanced differentiation of adipocytes is rather known as a characteristic of DR (Higami et al. 2004). Secondly, it was shown that re-feeding after fasting stimulates the expression of Srebf1 (Liang et al. 2002), which implies that the dietary restricted animals in our study are still $(6 \mathrm{~h}$ after feeding) in a postprandial state. A result that is consistent to a study by Bruss et al. (2010) is that DR elevates fatty acid synthesis in mice until 4-6 h after food provision compared to normal fed mice as measured by their respiratory exchange ratio. Our study confirms this finding and implicates an important role for Srebf1 and Srebf2 in this metabolic adaptation. 
Finally, upregulation of metabolic rate has earlier been observed in 'normal' low-fat DR studies in mice (Higami et al. 2004), as well as in dietary restricted nematodes (Houthoofd et al. 2002) and flies (Hulbert et al. 2004). The main difference in these studies is, however, that our results primarily point in the direction of lipid metabolism, implying that mice are capable of adjusting their metabolism specifically to their diet. As a result, HF-DR mice seem to be better equipped to deal with the excess amount of fat in their diet compared to the HF-AL mice. Several aspects of the microarray results fit within this theory. The upregulation of, for example, mitochondrial fatty acid $\beta$-oxidation (Fig. 5), in which acyl-CoA molecules are oxidized to generate acetyl-CoA that can be subsequently used in the citric acid cycle, enables HF-DR animals to synthesize ATP during scarcity of pyruvate. Pdk1 that was also upregulated by HF-DR complements this process by protecting carbohydrate stores in muscle (Peters et al. 2001) and, in this way, stimulates cells to shift to fat utilization and spare carbohydrate stores. Finally, the upregulation of Stard4 and Stard5 could make the metabolism of cholesterol more efficient by regulating the transfer of cholesterol to different cellular compartments. Apart from that, by binding, transporting, and positioning dietary cholesterol, STARD4 protein increases cholesteryl ester formation and is, therefore, postulated to play a role in the determination of serum total cholesterol and LDL-cholesterol (Riegelhaupt et al. 2010), which were found to be significantly decreased in serum of HF-DR mice (Fig. 3).

\section{HF-DR significantly enhanced mitochondrial function and density in WAT}

The mitochondrion serves a critical function in the maintenance of cellular energy stores, thermogenesis, and apoptosis. Proper control of mitochondrial function is, therefore, of major importance for cell survival and the maintenance of metabolic health. In our list of strongly regulated genes, we identified several genes that are involved in mitochondrial function (Table 3). The expression patterns of these genes pointed toward an improved mitochondrial function. To further confirm this finding, we analyzed our complete set of regulated genes for genes that are better established to play a key role in the regulation of mitochondrial function (Table 4). In the first place, we aimed at genes involved in the process of mitochondrial biogenesis. Mitochondrial biogenesis is mainly determined by genes that promote the formation of elements of the respiratory chain and the maintenance of mitochondrial DNA. Ppargc1a, Ppargc1b, and Esrra are known as the key transcriptional regulators within this process and were all significantly upregulated in HF-DR animals.
Nrf1, Gabpa, and Tfam that work as the direct effectors of Ppargc1a and stimulated mitochondrial biogenesis (Scarpulla 2008) were consistently upregulated in these animals. In addition, we found a significant increase in the expression of $\operatorname{Cox} I V$ and $\operatorname{CoxV} b$ that are under transcriptional control of $N r f 1$ and Gabpa and serve a direct function in the formation of the cytochrome oxidase subunits (Kelly \& Scarpulla 2004).

Secondly, we looked at genes involved in mitochondrial dynamics, which can be characterized by the degree of fission and fusion of mitochondria. Fission and fusion refers to the formation and breakdown of tubules between mitochondria, which plays an important role in the regulation of mitochondrial morphology. Dysregulation of genes involved in fission and fusion relates to the development of various disorders, such as diabetes (Yoon et al. 2010). In mammals, fission is primarily regulated by Dnml1 and Fis 1, both of which are upregulated by HF-DR, although the regulation of Fis1 is only marginally significant. Fusion of mitochondrial tubules is mediated by $M f n 1$ and Opa1, both of which are significantly upregulated in HF-DR mice. Opal is specifically involved in the fusion of the mitochondrial inner membrane and was found to be cleaved and activated by Omal, which is also significantly upregulated in our dataset. Finally, we also found a significant upregulation in the expression of Stoml2 and Dhodh that play a role in stress-induced fusion and the transcriptional regulation of fission respectively. Under normal conditions, fission and fusion proteins are expressed in response to the mitochondrial activity of the cell. Artificial overexpression of one of either fission or fusion proteins disrupts the balance and disturbs normal cell function (Yoon et al. 2010). Fis1 overexpression in liver cells, for example, causes mitochondrial fragmentation and impaired glucose-stimulated insulin secretion, whereas overexpression of $M f n 1$ causes similar perturbations of the metabolism-secretion coupling of glucose (Park et al. 2008). Regarding the improved health status of HF-DR mice, we hypothesize that the upregulation of both fission and fusion proteins relates to the observed improvement of mitochondrial function.

Fission and fusion proteins are, additionally, involved in the regulation of apoptosis by the elimination of damaged mitochondria by autophagy. Selective autophagy of mitochondria, or mitophagy, has extensively been described in yeast, where it is known to play an important role in the determination of cell survival or cell death after oxidative stress (Kanki \& Klionsky 2010). In short, damaged, aged, or excess mitochondria are a risk factor for the cell, and proper elimination of such organelles is important to maintain optimal cellular homeostasis. To also investigate the end stage of mitochondrial function, we analyzed a number of genes involved in mitochondrial autophagy. In mammals, 
mitophagy is regulated by Bnip3, Bnip3l, and Park2 (Narendra et al. 2008, Zhang \& Ney 2009), of which the latter two were significantly upregulated in HF-DR mice. Finally, we analyzed the expression of Mtor, a serine/threonine protein kinase transcription factor that responds to nutrient starvation, oxidative stress, and availability of growth factors. In fact, nutrient starvation and oxidative stress inhibit Mtor transcription, which stimulates autophagy and apoptosis (Jung et al. 2010). Mtor appeared to be significantly highly expressed in HF-DR animals, which implies a decreased prevalence of oxidative damage and apoptosis. The downstream effectors of Mtor, Ulk1 and Ulk2, that initiate apoptosis in the absence of Mtor were either not regulated or significantly downregulated.

It should be noted that DR is often related to downregulation of Mtor (Kenyon 2010). In this case, increase in autophagy is seen as a strategy to survive low nutrient concentrations by recycling their own cell content. In our study, however, the restriction of the HF diet still provides the animals with an amount of calories that is similar to the amount of calories that mice consume on a standard low-fat rodent diet: the HF-DR mice received $9.2 \mathrm{kcal} /$ day, whereas an 'average' male $C 57 B L 6 / J$ mouse eats around $10.8 \mathrm{kcal} /$ day (Champy et al. 2008). It can, therefore, be hypothesized that the HF-DR mice received sufficient nutrients and therefore did not need to switch to salvage pathways such as autophagy.

To summarize, microarray analysis provided us with a convincing amount of evidence for the upregulation of mitochondrial function in HF-DR mice. The increase in the ratio of mitochondrial DNA in WAT of HF-DR mice, which can be seen as an estimation of the mitochondrial density (Lagouge et al. 2006), further confirms our findings regarding the upregulation of mitochondrial genes. Although the promotion of mitochondrial biogenesis induced by caloric restriction was recently re-evaluated in an extensive restriction study in rats, in which no changes were found in the amount of mitochondrial proteins in restricted animals (Hancock et al. 2010), improvements of mitochondrial function in WAT were earlier observed in other restricted animals and is thought to be related to the beneficial effects of restriction (Higami et al. 2004, Linford et al. 2007), in which our study is the first to report effects on mitochondrial function in mice restricted on a HF diet.

\section{Conclusions}

The results of our study prove that DR can reverse the adverse effects of an initial unhealthy HF diet. Our treatment had a large influence on gene expression in WAT. An in-depth study on genes with the strongest $P$ values revealed a major role for genes involved in lipid metabolism and mitochondrial functioning. It is hypothesized that the restriction procedure has forced the metabolism of mice toward the utilization of especially lipids in order to effectively make use of the diet, spare carbohydrates, and to create a stable energy balance. The effective use of fat seems to protect HF-DR mice from the increase in serum cholesterol and leptin levels that were found in HF-AL mice, as well as from the decrease in mitochondrial density in WAT, and decrease in glucose sensitivity and serum adiponectin levels.

\section{Declaration of interest}

The authors declare that there is no conflict of interest that could be perceived as prejudicing the impartiality of the research reported.

\section{Funding}

The research leading to these results has received funding from the European Union's Seventh Framework Programme FP7 2007-2013 under grant agreement no. 244995 (BIOCLAIMS Project).

\section{Acknowledgements}

We thank all members of the Department of Human and Animal Physiology and RIKILT Food Bioactives group for their helpful contributions, especially Melissa Bekkenkamp and Marianne van der Mark for their help with the OGTT and qRT-PCR, and everyone from the animal facility who was involved in this study.

\section{References}

Ando H, Yanagihara H, Hayashi Y, Obi Y, Tsuruoka S, Takamura T, Kaneko S \& Fujimura A 2005 Rhythmic messenger ribonucleic acid expression of clock genes and adipocytokines in mouse visceral adipose tissue. Endocrinology 146 5631-5636. (doi:10.1210/en.20050771)

Anzulovich A, Mir A, Brewer M, Ferreyra G, Vinson C \& Baler R 2006 Elovl3: a model gene to dissect homeostatic links between the circadian clock and nutritional status. Journal of Lipid Research $\mathbf{4 7}$ 2690-2700. (doi:10.1194/jlr.M600230-JLR200)

de Boer VC, van Schothorst EM, Dihal AA, van der Woude H, Arts IC, Rietjens IM, Hollman PC \& Keijer J 2006 Chronic quercetin exposure affects fatty acid catabolism in rat lung. Cellular and Molecular Life Sciences 63 2847-2858. (doi:10.1007/s00018-0066316-z)

Brown MS \& Goldstein JL 1997 The SREBP pathway: regulation of cholesterol metabolism by proteolysis of a membrane-bound transcription factor. Cell 89 331-340. (doi:10.1016/S00928674(00)80213-5)

Bruss MD, Khambatta CF, Ruby MA, Aggarwal I \& Hellerstein MK 2010 Calorie restriction increases fatty acid synthesis and whole body fat oxidation rates. American Journal of Physiology. Endocrinology and Metabolism 298 E108-E116. (doi:10.1152/ajpendo.00524.2009)

Champy MF, Selloum M, Zeitler V, Caradec C, Jung B, Rousseau S, Pouilly L, Sorg T \& Auwerx J 2008 Genetic background determines metabolic phenotypes in the mouse. Mammalian Genome 19 318-331. (doi:10.1007/s00335-008-9107-z) 
Choi YS, Goto S, Ikeda I \& Sugano M 1988 Age-related changes in lipid metabolism in rats: the consequence of moderate food restriction. Biochimica et Biophysica Acta 963 237-242. (doi:10.1016/00052760(88)90286-X)

Combs TP, Berg AH, Rajala MW, Klebanov S, Iyengar P, JimenezChillaron JC, Patti ME, Klein SL, Weinstein RS \& Scherer PE 2003 Sexual differentiation, pregnancy, calorie restriction, and aging affect the adipocyte-specific secretory protein adiponectin. Diabetes 52 268-276. (doi:10.2337/diabetes.52.2.268)

Cretenet G, Le Clech M \& Gachon F 2010 Circadian clock-coordinated $12 \mathrm{hr}$ period rhythmic activation of the IRElalpha pathway controls lipid metabolism in mouse liver. Cell Metabolism 11 47-57. (doi:10. 1016/j.cmet.2009.11.002)

Dahlman I, Forsgren M, Sjogren A, Nordstrom EA, Kaaman M, Naslund E, Attersand A \& Arner P 2006 Downregulation of electron transport chain genes in visceral adipose tissue in type 2 diabetes independent of obesity and possibly involving tumor necrosis factor-alpha. Diabetes 55 1792-1799. (doi:10.2337/db05-1421)

Dhahbi JM, Mote PL, Wingo J, Rowley BC, Cao SX, Walford RL \& Spindler SR 2001 Caloric restriction alters the feeding response of key metabolic enzyme genes. Mechanisms of Ageing and Development 122 1033-1048. (doi:10.1016/S0047-6374(01)00230-5)

Friedewald WT, Levy RI \& Fredrickson DS 1972 Estimation of the concentration of low-density lipoprotein cholesterol in plasma, without use of the preparative ultracentrifuge. Clinical Chemistry 18 499-502.

Hancock CR, Han DH, Higashida K, Kim SH \& Holloszy JO 2010 Does calorie restriction induce mitochondrial biogenesis? A reevaluation. FASEB Journal 25 785-791. (doi:10.1096/fj.10-170415)

van Helden YG, Heil SG, van Schooten FJ, Kramer E, Hessel S, Amengual J, Ribot J, Teerds K, Wyss A, Lietz G et al. 2010 Knockout of the Bcmol gene results in an inflammatory response in female lung, which is suppressed by dietary beta-carotene. Cellular and Molecular Life Sciences 67 2039-2056. (doi:10.1007/ s00018-010-0341-7)

Higami Y, Pugh TD, Page GP, Allison DB, Prolla TA \& Weindruch R 2004 Adipose tissue energy metabolism: altered gene expression profile of mice subjected to long-term caloric restriction. FASEB Journal 18 415-417. (doi:10.1096/fj.03-0678fje)

Hochberg Y \& Benjamini Y 1990 More powerful procedures for multiple significance testing. Statistics in Medicine 9 811-818. (doi:10.1002/sim.4780090710)

Houthoofd K, Braeckman BP, Lenaerts I, Brys K, De Vreese A, Van Eygen S \& Vanfleteren JR 2002 No reduction of metabolic rate in food restricted Caenorhabditis elegans. Experimental Gerontology 37 1359-1369. (doi:10.1016/S0531-5565(02)00172-9)

Hulbert AJ, Clancy DJ, Mair W, Braeckman BP, Gems D \& Partridge L 2004 Metabolic rate is not reduced by dietary-restriction or by lowered insulin/IGF-1 signalling and is not correlated with individual lifespan in Drosophila melanogaster. Experimental Gerontology 39 1137-1143. (doi:10.1016/j.exger.2004.04.006)

Jager S, Bucci C, Tanida I, Ueno T, Kominami E, Saftig P \& Eskelinen EL 2004 Role for Rab7 in maturation of late autophagic vacuoles. Journal of Cell Science 117 4837-4848. (doi:10.1242/jcs.01370)

Jung CH, Ro SH, Cao J, Otto NM \& Kim DH 2010 mTOR regulation of autophagy. FEBS Letters 584 1287-1295. (doi:10.1016/j.febslet.2010. 01.017)

Kalupahana NS, Voy BH, Saxton AM \& Moustaid-Moussa N 2011 Energy-restricted high-fat diets only partially improve markers of systemic and adipose tissue inflammation. Obesity 19 245-254. (doi:10.1038/oby.2010.196)

Kanki T \& Klionsky DJ 2010 The molecular mechanism of mitochondria autophagy in yeast. Molecular Microbiology 75 795-800. (doi:10.1111/j.1365-2958.2009.07035.x)

Keijer J \& van Schothorst EM 2008 Adipose tissue failure and mitochondria as a possible target for improvement by bioactive food components. Current Opinion in Lipidology 19 4-10. (doi:10. 1097/MOL.0b013e3282f39f95)
Kelly DP \& Scarpulla RC 2004 Transcriptional regulatory circuits controlling mitochondrial biogenesis and function. Genes and Development 18 357-368. (doi:10.1101/gad.1177604)

Kenyon CJ 2010 The genetics of ageing. Nature 464 504-512. (doi:10. 1038 /nature08980)

Kopelman PG 2000 Obesity as a medical problem. Nature 404 635-643. (doi:10.1038/35007508)

Lagouge M, Argmann C, Gerhart-Hines Z, Meziane H, Lerin C, Daussin F, Messadeq N, Milne J, Lambert P, Elliott P et al. 2006 Resveratrol improves mitochondrial function and protects against metabolic disease by activating SIRT1 and PGC-1alpha. Cell 127 1109-1122. (doi:10.1016/j.cell.2006.11.013)

Lambert AJ, Wang B, Yardley J, Edwards J \& Merry BJ 2004 The effect of aging and caloric restriction on mitochondrial protein density and oxygen consumption. Experimental Gerontology 39 289-295. (doi:10. 1016/j.exger.2003.12.009)

Lara-Castro C, Newcomer BR, Rowell J, Wallace P, Shaughnessy SM, Munoz AJ, Shiflett AM, Rigsby DY, Lawrence JC, Bohning DE et al. 2008 Effects of short-term very low-calorie diet on intramyocellular lipid and insulin sensitivity in nondiabetic and type 2 diabetic subjects. Metabolism 57 1-8. (doi:10.1016/j.metabol.2007.05.008)

Ledikwe JH, Blanck HM, Kettel Khan L, Serdula MK, Seymour JD, Tohill BC \& Rolls BJ 2006 Dietary energy density is associated with energy intake and weight status in US adults. American Journal of Clinical Nutrition 83 1362-1368.

Lee CK, Klopp RG, Weindruch R \& Prolla TA 1999 Gene expression profile of aging and its retardation by caloric restriction. Science $\mathbf{2 8 5}$ 1390-1393. (doi:10.1126/science.285.5432.1390)

Lee CK, Allison DB, Brand J, Weindruch R \& Prolla TA 2002 Transcriptional profiles associated with aging and middle age-onset caloric restriction in mouse hearts. PNAS 99 14988-14993. (doi:10. 1073/pnas.232308999)

Leonard AE, Pereira SL, Sprecher H \& Huang YS 2004 Elongation of long-chain fatty acids. Progress in Lipid Research 43 36-54. (doi:10. 1016/S0163-7827(03)00040-7)

Li B, Shin J \& Lee K 2009 Interferon-stimulated gene ISG12b1 inhibits adipogenic differentiation and mitochondrial biogenesis in 3T3-L1 cells. Endocrinology 150 1217-1224. (doi:10.1210/en.2008-0727)

Liang G, Yang J, Horton JD, Hammer RE, Goldstein JL \& Brown MS 2002 Diminished hepatic response to fasting/refeeding and liver $\mathrm{X}$ receptor agonists in mice with selective deficiency of sterol regulatory element-binding protein-1c. Journal of Biological Chemistry 277 9520-9528. (doi:10.1074/jbc.M111421200)

Lin J, Yang R, Tarr PT, Wu PH, Handschin C, Li S, Yang W, Pei L, Uldry M, Tontonoz P et al. 2005 Hyperlipidemic effects of dietary saturated fats mediated through PGC-1beta coactivation of SREBP. Cell 120 261-273. (doi:10.1016/j.cell.2004.11.043)

Linford NJ, Beyer RP, Gollahon K, Krajcik RA, Malloy VL, Demas V, Burmer GC \& Rabinovitch PS 2007 Transcriptional response to aging and caloric restriction in heart and adipose tissue. Aging Cell $\mathbf{6}$ 673-688. (doi:10.1111/j.1474-9726.2007.00319.x)

Matsuzaka T, Shimano H, Yahagi N, Yoshikawa T, Amemiya-Kudo M, Hasty AH, Okazaki H, Tamura Y, Iizuka Y, Ohashi K et al. 2002 Cloning and characterization of a mammalian fatty acyl-CoA elongase as a lipogenic enzyme regulated by SREBPs. Journal of Lipid Research 43 911-920.

de Meijer VE, Le HD, MeiselJA, Sharif MR, Pan A, Nose V \& Puder M 2010 Dietary fat intake promotes the development of hepatic steatosis independently from excess caloric consumption in a murine model. Metabolism 59 1092-1105. (doi:10.1016/j.metabol.2009.11.006)

Nadler ST, Stoehr JP, Schueler KL, Tanimoto G, Yandell BS \& Attie AD 2000 The expression of adipogenic genes is decreased in obesity and diabetes mellitus. PNAS 97 11371-11376. (doi:10.1073/pnas. 97.21.11371)

Narendra D, Tanaka A, Suen DF \& Youle RJ 2008 Parkin is recruited selectively to impaired mitochondria and promotes their autophagy. Journal of Cell Biology 183 795-803. (doi:10.1083/jcb. 200809125) 
Oberkofler H, Fukushima N, Esterbauer H, Krempler F \& Patsch W 2002 Sterol regulatory element binding proteins: relationship of adipose tissue gene expression with obesity in humans. Biochimica et Biophysica Acta 1575 75-81. (doi:10.1016/S0167-4781(02)00279-8)

Ogden CL, Carroll MD, Curtin LR, Lamb MM \& Flegal KM 2010 Prevalence of high body mass index in US children and adolescents, 2007-2008. Journal of the American Medical Association 303 242-249. (doi:10.1001/jama.2009.2012)

Park SK \& Prolla TA 2005 Lessons learned from gene expression profile studies of aging and caloric restriction. Ageing Research Reviews 4 55-65. (doi:10.1016/j.arr.2004.09.003)

Park KS, Wiederkehr A, Kirkpatrick C, Mattenberger Y, Martinou JC, Marchetti P, Demaurex N \& Wollheim CB 2008 Selective actions of mitochondrial fission/fusion genes on metabolism-secretion coupling in insulin-releasing cells. Journal of Biological Chemistry 283 33347-33356. (doi:10.1074/jbc.M806251200)

Pellis L, Franssen-van Hal NL, Burema J \& Keijer J 2003 The intraclass correlation coefficient applied for evaluation of data correction, labeling methods, and rectal biopsy sampling in DNA microarray experiments. Physiological Genomics 16 99-106. (doi:10.1152/ physiolgenomics.00111.2003)

Peters SJ, Harris RA, Wu P, Pehleman TL, Heigenhauser GJ \& Spriet LL 2001 Human skeletal muscle PDH kinase activity and isoform expression during a 3-day high-fat/low-carbohydrate diet. American Journal of Physiology. Endocrinology and Metabolism 281 E1151-E1158.

Petro AE, Cotter J, Cooper DA, Peters JC, Surwit SJ \& Surwit RS 2004 Fat, carbohydrate, and calories in the development of diabetes and obesity in the C57BL/6J mouse. Metabolism 53 454-457. (doi:10. 1016/j.metabol.2003.11.018)

Prentice AM \& Jebb SA 2003 Fast foods, energy density and obesity: a possible mechanistic link. Obesity Reviews 4 187-194. (doi:10.1046/ j.1467-789X.2003.00117.x)

Reimer RA, Maurer AD, Lau DC \& Auer RN 2010 Long-term dietary restriction influences plasma ghrelin and GOAT mRNA level in rats. Physiology and Behavior 99 605-610. (doi:10.1016/j.physbeh.2010.01. 034)

Rezzi S, Martin FP, Shanmuganayagam D, Colman RJ, Nicholson JK \& Weindruch R 2009 Metabolic shifts due to long-term caloric restriction revealed in nonhuman primates. Experimental Gerontology 44 356-362. (doi:10.1016/j.exger.2009.02.008)

Riegelhaupt JJ, Waase MP, Garbarino J, Cruz DE \& Breslow JL 2010 Targeted disruption of steroidogenic acute regulatory protein $\mathrm{D} 4$ leads to modest weight reduction and minor alterations in lipid metabolism. Journal of Lipid Research 51 1134-1143. (doi:10.1194/jlr. M003095)

Rodriguez-Agudo D, Ren S, Wong E, Marques D, Redford K, Gil G, Hylemon P \& Pandak WM 2008 Intracellular cholesterol transporter StarD4 binds free cholesterol and increases cholesteryl ester formation. Journal of Lipid Research 49 1409-1419. (doi:10.1194/jlr. M700537-JLR200)

Scarpulla RC 2008 Transcriptional paradigms in mammalian mitochondrial biogenesis and function. Physiological Reviews 88 611-638. (doi:10.1152/physrev.00025.2007)

van Schothorst EM, Franssen-van Hal N, Schaap MM, Pennings J, Hoebee B \& Keijer J 2005 Adipose gene expression patterns of weight gain suggest counteracting steroid hormone synthesis. Obesity Research 13 1031-1041. (doi:10.1038/oby.2005.121) van Schothorst EM, Keijer J, Pennings JL, Opperhuizen A, van den Brom CE, Kohl T, Franssen-van Hal NL \& Hoebee B 2006

Adipose gene expression response of lean and obese mice to shortterm dietary restriction. Obesity 14 974-979. (doi:10.1038/oby.2006. 111)

van Schothorst EM, Pagmantidis V, de Boer VC, Hesketh J \& Keijer J 2007 Assessment of reducing RNA input for Agilent oligo microarrays. Analytical Biochemistry 363 315-317. (doi:10.1016/j.ab. 2007.01.016)

van Schothorst EM, Bunschoten A, Schrauwen P, Mensink RP \& Keijer J $2009 a$ Effects of a high-fat, low- versus high-glycemic index diet: retardation of insulin resistance involves adipose tissue modulation. FASEB Journal 23 1092-1101. (doi:10.1096/fj.08-117119)

van Schothorst EM, Flachs P, Franssen-van Hal NL, Kuda O, Bunschoten A, Molthoff J, Vink C, Hooiveld GJ, Kopecky J \& Keijer J $2009 b$ Induction of lipid oxidation by polyunsaturated fatty acids of marine origin in small intestine of mice fed a high-fat diet. $B M C$ Genomics 10 110. (doi:10.1186/1471-2164-10-110)

Semple RK, Crowley VC, Sewter CP, Laudes M, Christodoulides C, Considine RV, Vidal-Puig A \& O'Rahilly S 2004 Expression of the thermogenic nuclear hormone receptor coactivator PGClalpha is reduced in the adipose tissue of morbidly obese subjects. International Journal of Obesity and Related Metabolic Disorders 28 176-179. (doi:10.1038/sj.ijo.0802482)

Sobel BE, Frye R \& Detre KM 2003 Burgeoning dilemmas in the management of diabetes and cardiovascular disease: rationale for the Bypass Angioplasty Revascularization Investigation 2 Diabetes (BARI 2D) Trial. Circulation 107 636-642. (doi:10.1161/01.CIR. 0000048897.03553.E4)

Soukas A, Cohen P, Socci ND \& Friedman JM 2000 Leptin-specific patterns of gene expression in white adipose tissue. Genes and Development 14 963-980. (doi:10.1101/gad.14.8.963)

Strable MS \& Ntambi JM 2010 Genetic control of de novo lipogenesis: role in diet-induced obesity. Critical Reviews in Biochemistry and Molecular Biology 45 199-214. (doi:10.3109/10409231003667500)

Trayhurn P \& Beattie JH 2001 Physiological role of adipose tissue: white adipose tissue as an endocrine and secretory organ. Proceedings of the Nutrition Society 60 329-339. (doi:10.1079/ PNS200194)

Weindruch R, Naylor PH, Goldstein AL \& Walford RL 1988 Influences of aging and dietary restriction on serum thymosin alpha 1 levels in mice. Journal of Gerontology 43 B40-B42. (doi:10.1093/geronj/43.2. B40)

Wettenhall JM \& Smyth GK 2004 limmaGUI: a graphical user interface for linear modeling of microarray data. Bioinformatics 20 3705-3706. (doi:10.1093/bioinformatics/bth449)

Yoon Y, Galloway CA, Jhun BS \& Yu T 2010 Mitochondrial dynamics in diabetes. Antioxidants and Redox Signaling 14 439-457. (doi:10.1089/ ars.2010.3286)

Zhang J \& Ney PA 2009 Role of BNIP3 and NIX in cell death, autophagy, and mitophagy. Cell Death and Differentiation 16 939-946. (doi:10.1038/cdd.2009.16)

Received in final form 25 March 2011

Accepted 23 May 2011

Made available online as an Accepted Preprint 24 May 2011 